\title{
6 Paradigmatic split and merger: The descriptive and diachronic problem of Old Irish Class B infixed pronouns
}

\section{Introduction: Infixed pronouns and clause types in the Old Irish verbal complex}

Infixed pronouns are one of the formal strategies used in the Old Irish verbal complex to distinguish clause types, in such a manner that the sole formal opposition between Classes A/B and Class $C$ serves to express the opposition between declarative and relative clause type respectively in lexical compound verbs which take an infixed pronoun.

The use of the Classes A and B of infixed pronouns, which mark declarative clause type, is determined by the phonotactic structure of the (first) lexical preverb of the verbal compound appearing in the pretonic part of the verbal complex. The general rule is that lexical preverbs which end with a consonant (henceforth also (-)VC- lexical preverbs), with the exception of imm- and ar-, take Class B infixes to express declarative clause type. For instance, the Old Irish verb as.beir '(s)he says', with the (-)VC- preverb as-, takes the Class B third person singular neuter infixed form $-t^{\mathrm{L}}$-, so that $a(s)-+-t^{\mathrm{L}}-\rightarrow$ at-in at $\cdot$ beir ' (s)he says it'. By contrast, lexical preverbs which end with a vowel (henceforth also CV- lexical preverbs) make use of the so-called Class A of infixed pronouns, so that e.g. the lexical compound do beir '(s)he brings, gives', with the lexical preverb (to- >) do-, expresses the same third person singular neuter pronominal reference by substituting the - $o$ - vowel of the lexical preverb by the corresponding Class $\mathrm{A}$ infixed form $-a^{\mathrm{L}}$, i.e. $d(o)-+-a^{\mathrm{L}}-\rightarrow$ da beir '(s)he brings, gives it'. The lexical preverbs imm- and ar-also make use of Class A of infixed pronouns.

The relative forms which minimally contrast in clause type with the above mentioned declarative forms at.beir '(s)he says it' and da.beir '(s)he brings, gives it' are ass-id·beir 'who says it' and do-d·beir 'who gives it' respectively, which include the mentioned Class $\mathrm{C}$ forms of the third person neuter infixed pronoun (i.e. - $[i] d^{\mathrm{L}}$-).

The ultimate aim of this study is to explain the diachronic origin of Class $\mathrm{B}$ of infixed pronouns, but, as a prerrequisite for this, and also as a point which is in itself worth discussing, the exact morphological and syntactic circumstances of these infixed pronouns must also be investigated in the corpus

Ә Open Access. (C) 2020 Carlos García-Castillero, published by De Gruyter. (c) BY-NC-ND This work is licensed under the Creative Commons Attribution-NonCommercial-NoDerivatives 4.0 International License. https://doi.org/10.1515/9783110680744-007 
of the contemporaneous Old Irish glosses. This descriptive question can be briefly referred to as follows. The distinction between Classes A/B (for declarative clause type forms) and Class C (for relative clause type forms) is quite regularly made in Old Irish when a third person pronoun is infixed in the lexical compound. However, things are different with a first or second (henceforth also non-third) person pronominal infix. In the language of the contemporaneous Old Irish texts, non-third person infixed pronouns are much less regular in making that distinction between declarative and relative form and show a very remarkable behaviour especially when the lexical preverb after which the infixed pronoun appears is of type (-)VC-, that is to say, when the declarative clause type infixed pronoun must be of Class B. In that situation, Class B is most often used in cases in which relative clause morphology (i.e. a Class C form) is expected. Though less frequently, nonthird person Class A infixed pronouns also appear in cases in which relative morphology is expected.

The descriptive question is then how to deal with this asymmetry in the use of Classes C and B depending on whether the involved infix is of a third or non-third person, and the position taken in this paper is that this situation of asymmetry observed in the contemporaneous Old Irish texts is directly related to the question on the diachronic origin of the Class B of infixed pronouns.

In order to answer this question, sections 2 to 4 provide a detailed description of the situation of Class B pronouns as they are used in the Old Irish glosses. In particular, section 2 provides basic information about the Old Irish verbal complex and the category of clause typing expressed in it; section 3 provides a list of lexical preverbs which take either Classes A or B of infixed pronouns, presents the whole paradigm of the three classes of infixed pronouns, and illustrates the use of Classes A/B instead of the expected Class C; section 4 lists the forms attested in the three main collections of glosses which show a non-third person infixed pronoun after a pretonic lexical preverb of the (-)VCtype, that is to say, of verbs which must take Class B for the declarative clause type forms. On the basis of the previous description, section 5 gives a proper formulation for the diachronic question referred to above, discusses previous diachronic explanations, and provides some basic aspects regarding the etymology of the other classes of infixed pronouns, as well as of some lexical preverbs. Section 6 elaborates a diachronic explanation for the Old Irish Class B of infixed pronouns which is congruent with the previous description and which also provides a justification for this formal distinction in the infixed pronouns used for declarative clause type. Section 7 summarises the main points of the paper. 


\section{Some background about the Old Irish verbal complex}

The initial statement of this paper is, as stated above, that Classes A/B of infixed pronouns are used for declarative and Class $C$ for relative clause types. This section only refers to two issues on these pronominal references. For more aspects of the Old Irish verbal complex, I refer to the treatment in GarcíaCastillero (2012, 2014, 2015, 2020).

The first issue is that the Old Irish infixed pronouns are morphological elements which always appear after a previous pretonic element, which may be a conjunct particle (i.e. a pretonic element of a grammatical nature), or a lexical preverb, which constitutes a semantic unit with the verbal stem (see Table 1 below on page 148). Handbook examples of the combination of a verb with conjunct particles are níbeir and nad.beir, from the simple beirid 'brings'. Both being the third person singular of the present indicative active, the former is marked as a negative declarative clause type form ('[s] he does not bring'), and the latter as a negative relative clause type form ('who does not bring' or 'whom/which s/he does not bring'). The form nad.beir must be understood as including relative lenition (i.e. the change of underlying $/ \mathrm{b}^{\mathrm{j}} /$ to $/ \mathrm{v}^{\mathrm{j}} /$ producing $/$ na $^{\prime}{ }^{\mathrm{j}} \mathrm{v}^{\mathrm{j}} \mathrm{r}^{\mathrm{j}} /$ ), although this mutation is not graphically marked in Old Irish when it applies to voiced obstruents. Relative lenition involves the phonological fricativisation of the first consonant of the basic form of the verb, in this case a voiced bilabial plosive; the sound /f/ is deleted and /s/ becomes an aspiration; vowels are not affected by lenition. The other relative mutation used in the Old Irish verbal complex is the socalled relative nasalisation, which formally involves the addition of a nasal sound to a voiced plosive (i.e. nad.mbeir), or to a vowel, and the voicing of a basic voiceless plosive. The functional side of these two relative mutations does not need to be considered now. The important point for the use of Class $B$ infixes is that it is only combined with the lexical preverbs of the type (-)VCto be observed in the next section, whereas Class A is combined with lexical preverbs (of the type CV-) and conjunct particles; by themselves, these two classes express declarative clause type. Class $\mathrm{C}$ infixes, which express relative clause type, are combined with lexical preverbs of whichever phonotactic type and conjunct particles.

The second issue is related to the two grammatical categories which crosscut in the infixed pronoun, which must therefore be considered basically as a portmanteau morpheme expressing pronominal reference and clause type at the same time. The Old Irish verbal complex regularly distinguishes six clause types by means of several formal procedures. The two most important clause 
types for this paper are the declarative and the relative (where the leniting and the nasalising variants mentioned must be included); in addition, the Old Irish verb distinguishes content (or wh-)interrogative, polar (or yes-no) interrogative, responsive and imperative clause type forms. Some of these clause types will be mentioned later, and are characterised by the use of one of the classes of pronominal infixes, as also detailed in the next section. As for the distinction between declarative and relative clause types, it must be stated that the formal opposition between Classes A/B and C is one of the formal strategies which suffice by themselves to distinguish those two clause types in the Old Irish verbal complex, as illustrated in the examples of (1) of the next section. The other formal means are different sets of endings (the so-called absolute endings, where there are both declarative and relative absolute endings), the so-called relative mutations (which contrast with the lack of them), as well as special conjunct particles such as the negative declarative $n i$ - and the negative relative nad- mentioned above.

\section{Formal and functional aspects of the Old Irish Classes A, B and C of pronominal infixes}

This section provides the basic descriptive tools to understand properly the problems considered in this paper. Section 3.1 illustrates the basic distinction referred to in the previous section with attested forms including third person singular neuter infixed forms. In section 3.2 the whole set of the infixed pronouns used in the Old Irish verbal complex as well as the main issues of their use are introduced, paying special attention to the formal features of Classes B and C. Section 3.3 centres on the morphological process which must be assumed in the expression of the third person singular masculine / neuter of Class A infixed pronouns. Section 3.4 establishes the proper context in which the asymmetry between third and non-third persons mentioned at the outset must be considered, and focuses on the use of Class A instead of expected Class $\mathrm{C}$ as a special case of the general phenomenon which involves the possibility of using either declarative or relative clause type marking in the same syntactic context.

\subsection{Basic functional distinction between Classes A/B and C}

Classes A and B basically mark the corresponding verbal complex as a declarative clause type verb, as already stated, and are also used in the imperative verb, which makes use of a partly different set of inflectional endings. The pronominal 
infixes of Class $\mathrm{C}$ are used to mark relative clause type and some other subordinate clauses, and are also used in polar interrogative clause type forms, which are constitutively marked by the conjunct particle $i{ }^{\mathrm{N}}{ }^{-}$. In lexical compounds which have no conjunct particle in the pretonic slot, i.e. which have a lexical preverb in the pretonic slot, this difference between Class A/B and Class C expresses by itself the difference between declarative and relative clause type respectively. The forms in (1) and (2) illustrate this clause type difference in minimal or quasiminimal pairs of forms attested in the Old Irish glosses.

(1) a. darigni

PV-3SG $\mathrm{NEUT}_{\mathrm{T}}(\mathrm{A}) \cdot \mathrm{do}_{\mathrm{AUG} .3 \mathrm{SG} . \mathrm{PRET}}$

'(David) has done it.' (Ml. 51 $\left.{ }^{\mathrm{d}} 2\right)$

b. dudrigni

PV-3SG NEUT $(\mathrm{C}) \cdot \mathrm{do}_{\mathrm{AUG} .3 \mathrm{SG} . \text { PRET }}$

'who has done it' (Ml. 124 3 )

(2)
a. air atroilli
dia
for $\mathrm{PV}-3 \mathrm{SG}_{\mathrm{NEUT}}(\mathrm{B}) \cdot$ deserve $_{3 \mathrm{SG} . \mathrm{PRES}} \mathrm{God}_{\mathrm{NOM}}$
'for God deserves it . . ' (Ml. 51 $\left.{ }^{\mathrm{d}} 12\right)$
b. donaib hi assidroillet

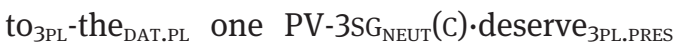
'to those that deserve it' (Ml. $\left.54^{\mathrm{d}} 6\right)$

The forms in (1) are both based on the third person singluar perfect active do.rigni '(s)he has done', of do.gní 'does, makes', where do- is a CV- lexical preverb. In (1a), this form takes the third person singular neuter infix of Class A, whereas in (1b), it takes the corresponding Class $C$ form. The two examples of (2) include forms from the verb ad·roilli 'deserves'. In (2a), at·roilli has the Class B third person singular neuter infix and therefore counts as a declarative clause type form. Note, in the relative form assidroillet in (2b), the use of the preverb asinstead of the original ad-: as stated by Thurneysen (GOI $\S 822$ ), this is due to the loss of formal distinctiveness between those preverbs as- and ad- when they are combined with Class B infixed pronouns, both with the form at-: cf. at-roilli '[God] deserves it' in (2a) and the form at.beir '(s)he says it' quoted in the introduction, which belongs to the basic form as.beir '(s)he says'. Though this is not exactly the case of the loss of formal distinctivity assumed later on in this paper as the trigger of the creation of the Old Irish Class B of infixed pronouns, it illustrates how formal distinctions can be lost in the pretonic part of the verbal complex. 


\subsection{The Old Irish lexical preverbs and the distribution of Classes A/B}

As also anticipated at the outset, the phonotactic structure of the (first) lexical preverb of the basic lexical compound decides the shape of the infixed pronoun expressing declarative clause type, i.e. whether Classes A or B are to be used. According to the description in GOI (§§ 411-412), the general rule is that, if the lexical preverb ends in a vowel, i.e. if it has the shape CV-, then Class A is used; if the lexical preverb ends in a consonant, i.e. (-)VC- (except imm- and ar-, which bear Class A infixes, which originally had the shape CV-, i.e. which come from a form with original vocalic auslaut), then the infixed pronouns of Class B are used. Table 1 includes the most relevant lexical preverbs in the shape that they adopt in Old Irish in declarative clauses without infixed pronoun, ${ }^{1}$ and - for the (-)VCpreverbs - it also gives the assumed Primitive Irish form between parentheses and the basic form that they adopt in combination with a Class B infixed pronoun.

Table 1: Old Irish lexical preverbs and their infix class in declarative clause type form.

\begin{tabular}{|c|c|c|c|c|}
\hline \multicolumn{2}{|c|}{ Lexical preverbs with Class A } & \multicolumn{3}{|c|}{ Lexical preverbs with Class B } \\
\hline $\begin{array}{l}\text { CV- } \\
\text { ro- } \\
\text { (to >) do- 'to' } \\
\text { di/e- / do- 'from' } \\
\text { fo- 'under' }\end{array}$ & $\begin{array}{l}\text { (-)VC- } \\
\text { imm- 'about' } \\
\text { ar- 'for' }\end{array}$ & $\begin{array}{l}(-) \text { VC- } \\
\left({ }^{\star} \text { kom }-\right) \\
\left({ }^{\star} \text { in }[d]-\right) \\
\left({ }^{\star} \text { ad }-\right) \\
\left({ }^{\star} \text { ath }[i]-\right) \\
\left({ }^{\star} \text { ess }-\right) \\
\left({ }^{\star} \text { uss- }\right) \\
\left({ }^{\star} \text { frith- }\right) \\
\left({ }^{\star} \text { for- }\right) \\
\left({ }^{\star} \text { eter- }\right)\end{array}$ & $\begin{array}{l}\text { con- 'with' } \\
\text { in (d)- 'in' } \\
\text { ad- 'to' } \\
\text { ad- 're-' } \\
\text { as- 'out of' } \\
\text { as- 'up, out'2 } \\
\text { fris- 'towards' } \\
\text { for- 'over' } \\
\text { eter- 'between' }\end{array}$ & $\begin{array}{l}\rightarrow \text { cot- } \\
\rightarrow \text { at- } \\
\rightarrow \text { at- } \\
\rightarrow \text { at- } \\
\rightarrow \text { at- } \\
\rightarrow \text { at- } \\
\rightarrow \text { frit- } \\
\rightarrow \text { fort-/d- } \\
\rightarrow \text { etart- } / d .\end{array}$ \\
\hline
\end{tabular}

The meanings adduced must be understood as orientative and, to a great extent, etymologically based. In not a few compounds, however, these meanings have been blurred, so that they are not anymore distinguished.

1 Class B is also found in combination with the de-adjectival preverb mi- 'badly, mis-' in mitnimret 'that they deceive him' $\left(\mathrm{Ml} .74^{\mathrm{b}} 22=m i-t^{\mathrm{N}}\right.$ imret, from the verb imm.beir 'plays, handles'). See García-Castillero (2014) for this type of preverbal element, which is much less frequent than the conjunct particles and lexical preverbs.

2 For this semantic interpretation, see Russell (1988: 125). 
Despite the fact that there are more preverbs which bear Class B, as it can be observed in Table 1, the ones taking Class A are more frequent, i.e. there are more verbal compounds with those lexical preverbs. In addition to that, whereas Class B is only used with the (-)VC- lexical preverbs, Class A is regularly used also with some very frequent conjunct particles such as the declarative negative particle ni- seen in the previous section, or the meaningless particle no-, one of whose main functions is precisely to provide a pretonic element after which the equally unstressed infixed pronoun can appear.

The combination resulting from the preverb with the Class A infix constitutes a phonotactically adequate sequence in most forms of the corresponding paradigm. The preverbs imm- and ar-, to use the pretonic forms used in declarative verbal complexes, are characterised by the addition of a vowel after the final consonant of the form before the Class A pronominal form. These two features are illustrated in Table 2, which includes the CV-lexical preverbs to- and di/e- with Class A infixed pronouns, and the combination of the former with Class $\mathrm{C}$, on the one hand, and the specific form of the preverb imm-, on the other. The (-)VC- lexical preverb included in Table 2 is con-, a type of preverb which ends with a nasal and in which the difference between Classes B and C is most conspicuous.

Table 2: Some Old Irish lexical preverbs with infixed pronouns of Classes A, B and C.

\begin{tabular}{|c|c|c|c|c|c|c|}
\hline & \multicolumn{3}{|c|}{ Class A } & \multirow{2}{*}{$\begin{array}{l}\text { Class B } \\
\text { con- }\end{array}$} & \multicolumn{2}{|c|}{ Class C } \\
\hline & to- & di/e- & imm- & & con- & to- \\
\hline $1 \mathrm{sg}$. & do-m- ${ }^{\mathrm{L}}$ & $d o-m-^{\mathrm{L}}$ & $i m m-u m-^{\mathrm{L}}$ & $\operatorname{cotam}{ }^{-\mathrm{L}}$ & condam ${ }^{\mathrm{L}}$ & do-dam ${ }^{\mathrm{L}}$ \\
\hline $2 \mathrm{sg}$. & $d o-t^{-}$ & $d o-t^{\mathrm{L}}$ & $i m m-u t^{\mathrm{L}}$ & cotat $^{\mathrm{L}}$ & condat $^{\mathrm{L}}$ & do-dat- ${ }^{\mathrm{L}}$ \\
\hline 3sg.masc. & $d(0)-a-^{N}$ & $d(i / e)-a-^{\mathrm{N}}$ & $i m m-a-^{\mathrm{N}}$ & $\cot ^{\mathrm{N}}$ & condid $^{\mathrm{N}}$ & $d o-d-^{\mathrm{N}}$ \\
\hline 3sg.neut. & $d(0)-a^{\mathrm{L}}$ & $d(i / e)-a^{-}$ & $i m m-a-{ }^{\mathrm{L}}$ & $\cot ^{-}$ & condid- ${ }^{\mathrm{L}}$ & $d o-d-{ }^{\mathrm{L}}$ \\
\hline 3sg.fem. & do-s- & do-s- & imm-us- & cota- & conda- & $d o-d a-$ \\
\hline $1 \mathrm{pl}$. & do-n- & $d o-n-$ & imm-un- & cotan- & condan- & do-dan- \\
\hline $2 \mathrm{pl}$. & $d o-b-$ & $d o-b-$ & $i m m-u b-$ & cotab- & condab- & $d o-d a b-$ \\
\hline $3 p l$. & $d o-s-^{\mathrm{N}}$ & $d o-s-^{\mathrm{N}}$ & imm-us- ${ }^{\mathrm{N}}$ & $\operatorname{cota}{ }^{\mathrm{N}}$ & conda- ${ }^{\mathrm{N}}$ & $d o-d a-^{\mathrm{N}}$ \\
\hline
\end{tabular}




\subsection{The morphology of the Class A and B infixed pronouns}

This section focuses on some pronominal infixes given in the previous section which involve morphological processes other than the mere addition of a segment. Specifically, I refer to the third person singular masculine / neuter forms of Class A and to the combination of some lexical preverbs with the Class B forms.

As for the third person singular masculine / neuter pronouns in CV- lexical preverbs such as (to- >) do- and di/e-/do- (see Table 2), it seems that the synchronically most adequate description of the morphological process concerned is that they are the outcome of a process of replacement or substitution of the final vowel of the preverb by the vowel - $a$ - plus the corresponding mutation. That is to say, the lexical preverbs (to- >) do-, di/e-/do-, ro-, fo- and the conjunct particle no- take out their vowel in order to include the vowel $-a$ - which characterises those two persons: e.g. $d o^{-}+-a^{-} / \mathrm{L} \rightarrow d(o)-a^{-}{ }^{\mathrm{N} / \mathrm{L}}$, i.e. $d a^{-}{ }^{\mathrm{N} / \mathrm{L}}$. This analysis is perfectly compatible with the diachronic process of vowel elision, to be considered in section 5 below. In this light, the Class A third person singular masculine / neuter infixes seem to be a good example of replacive morphology (cf. Spencer 1998: 140-141), and are relevant in the context of this paper for the following two reasons.

Firstly, the outcome of that process of morphological replacement may be the reason for the formal assimilation of the CV- lexical preverbs (to- >) do- and di/e-/ do- 'from' in pretonic position, a position in which their respective vowels should have been preserved as distinct. To be sure, the forms de and di can still be found in some verbs such as e.g. de.meccim 'I despise' $\left(\mathrm{Sg} .39^{\mathrm{b}} 1\right)$, but the extremely frequent compound do.gní 'does, makes' quoted above in (1), which is formed with the preverb de- 'from', has virtually only do- in pretonic position. In other words, I contend that one of the factors which led to the lack of distinction of the pretonic version of di/e- and (to- >) do- (both appearing in Old Irish as do- in most cases) was the substitution of the characteristic vowel of the preverb when it was combined with the third person singular $\mathrm{m} . / \mathrm{n}$. infixed pronoun $-a^{-}{ }^{\mathrm{N} / \mathrm{L}}$, where both the preverbs (to- >) do- and di/e- appeared in Old Irish as $d a^{-\mathrm{N} / \mathrm{L}}$. Other factors which have surely played a role in that process are the coincidence in the consonant due to the change (to- >) do- in pretonic position (see GOI §178.2) and, eventually, the loss of semantic identity of the element involved due to the lexicalisation of the meaning of the compound. All those conditions meet in the verb do.gní just quoted. The same reason has been adduced for the confusion of lexical preverbs with the shape (-)VC-, as in e.g. the form assidroillet quoted in example (2b) above. ${ }^{3}$

3 Not every case of loss of distinctiveness between lexical preverbs is left without response in Old Irish. The phenomenon known as 'split for' is in the end an attempt to maintain the 
Second, this idea of replacement as a morphological process operating in the combination of Old Irish lexical preverbs with infixed pronouns can be applied perfectly to Class B of infixed pronouns. Adopting the same synchronic perspective as for the Class A third person singular masculine / neuter forms above, the phonotactic combinations which can be considered for the (-)VC- lexical preverbs are the following: (a) the combination of the Class B of infixed pronouns with the preverbs which end with a nasal (con-, in-) implies that the final nasal is substituted by the assumed /d/ of the infixed pronoun (i.e. con- $+/ \mathrm{d}-/ \rightarrow$ cot- $/ \mathrm{kod} /$ ); the same replacive process seems to apply to the combination of Class B infixes with preverbs in -s, i.e. (ess-, uss- >) as- and fris-, which give at- and frit- respectively; (b) when combined with preverbs ending with $/ \mathrm{r} /$ (for-, etar-), then the Class B pronoun is simply added to the preverb form and its initial dental sound is spelt either as - $d$ - or as -t-; see the attested forms in Table 3 of section 4 below; (c) for the lexical preverbs in a dental fricative (e.g. ad- /að/), the process at stake seems to be that the assumed /d/ of the Class B infixed pronoun again takes the place of the final consonant of the preverb or, alternatively, that the consonant of the preverb and that of the infix have 'merged' into a fortis consonant.

The diachronic discussion on Class $B$ infixed pronouns is a matter of sections 5 and 6 below, but it is worth noting that the interpretation of the form of Class $B$ as containing a $/ d /$ sound is not the only one possible. In particular, the form at-corresponding to ad- /að/ may well be the outcome of a merger of the final lenis of the preverb and an initial lenis sound, as if it were $a d-/ \mathrm{a} / \mathrm{t} / \mathrm{\partial} />$ at- /ad/. A parallel process may be the case of nepuid 'not-being'/'nebuð ${ }^{\mathrm{j}} / \mathrm{de}$ rived from ${ }^{\star} n e \beta^{\prime} \beta u \theta^{\mathrm{i}}$ considered in GOI (§ 137).

\subsection{The use of Class A instead of Class C with 1st and 2nd person infixed pronouns}

In compound verbs with a lexical preverb of whichever phonotactic structure in the pretonic position and which include an infixed pronominal reference, the formal distinction between the infixed form marking declarative clause type (Classes A/B) and the infixed form marking relative clause type (Class $\mathrm{C}$ ) is regularly made with third person pronouns. This opposition has been already illustrated in examples (1) and (2) above.

difference between two semantically opposed lexical preverbs, for- 'over' and fo- 'under', in some specific morphological combinations in which they could be confused. See García-Castillero (2017) for this question. 
However, compound verbs taking a first or second person infix are less systematic in this regard, so that the pronominal infixes of Classes A and B sometimes appear in forms in which relative clause type morphology is expected. In fact, this alternation between declarative and relative clause type morphology is a widespread phenomenon in Old Irish, not restricted to infixed pronouns; the reader may consult Ó hUiginn's $(1986,1998)$ studies quoted below in this section.

One may therefore distinguish three groups of clauses according to whether declarative or relative clause type morphology (not only infixed pronouns) is associated with them. Group I consists of main declarative clauses and some specific subordinate clauses which are characterised by the regular use of declarative morphology. Group II consists of subordinate clauses which display both declarative and relative verbal forms. Group III consists of subordinate clauses which regularly show relative morphology. The verbal complex which has the relative conjunct particle $-(s) a^{\mathrm{N}}-$, as well as other conjunct particles such as the polar interrogative one already mentioned, are not mentioned in any of these groups because such conjunct particles do not appear in the attested forms included in Table 3 below.

(I) Verbs with declarative clause type morphology are regularly used in:

(a) main declarative clauses,

(b) cleft sentences with an anteposed oblique constituent (i.e. a prepositional phrase),

(c) adverbial subordinates introduced by $c o^{\mathrm{L}}$ 'so that', $m a^{\mathrm{L}}$ 'if', $c a^{\mathrm{L}}$ 'though'. 4

(II) Verbs with either (nasalising) relative or declarative clause type morphology are used in:

(d) in complement (or noun) subordinate clauses,

(e) in adverbial subordinate clauses introduced by iarsindi 'after', lase 'when' (mostly with a relative verb), amal 'as', (h)óre 'because'.

(III) Verbs with relative clause type morphology are regularly used in:

(f) restrictive relative clauses of the leniting or nasalising type,

4 In the language of the Glosses, a meaningless Class $C$ third person singular neuter infixed pronoun $-d^{\mathrm{L}}$ - appears regularly in the verbal complexes in indicative mood after the subordinating conjunctions $m a^{\mathrm{L}}$ 'if' and $\mathrm{cia}^{\mathrm{L}}$ 'though', provided that there is no other semantically full infixed pronoun. In line with the description in García-Castillero (2020, Chapter 5), this use of $-d^{\mathrm{L}}$ - is to be interpreted as the introduction of a marker of syntactic dependency. If these conditions are not met, these two subordinating conjunctions $\mathrm{ma}^{\mathrm{L}}$ 'if' and $\mathrm{cia}^{\mathrm{L}}$ 'though' are regularly followed by a declarative clause type verbal complex. I hope to deal with the subordinating conjunction $c o^{\mathrm{L}}$ 'so that' and its relationship with the almost synonymous conjunct particle $c o^{\mathrm{N}}$ - in a future study. 
(g) cleft-sentences with an anteposed subject or object NP (including cases of figura etymologica, which involve nasalising relative marking),

(h) relative clauses after the light heads $a^{\mathrm{N}}$ and inti ani, ${ }^{5}$ and in subordinate clauses after the temporal conjunctions $a^{\mathrm{N}}$ 'when' and inta(i)n 'when',

(i) relative clauses of types (f) after the stressed interrogative pronouns cia cid 'who, what'.

The observed variation between declarative and relative morphology in Group II is determined by various factors: see Ó hUiginn (1998: 126-130) for the variation in complement clauses, and García-Castillero (2020, ch. 5) for the variation in the third person singular of the copula after amal and (h)óre). Among these factors, person plays a prominent role. By person, I refer to the cases in which the involved verbal complex includes either only one pronominal reference expressed by means of an inflectional ending or two pronominal references, one of them an infixed pronoun. The general tendency is that non-third persons, whether in the inflectional ending or in the infixed pronoun (or in both), favour the use of declarative clause type morphology.

As an illustration consider (3), taken from Ó hUiginn (1986: 43, 45). Example (3a) shows relative morphology by means of the pretonic particle no- followed by nasalisation (graphically not marked in nocretim /no' ${ }^{\mathrm{j}}{ }^{\mathrm{e}} \mathrm{ed}$ $\mathrm{j}_{\mathrm{im}} /$ ), while pridchim in (3b), which lacks the pretonic particle, represents a declarative clause type form.
a. hóre nocretim ísu because $\mathrm{PV} \cdot{ }^{\mathrm{NAS}}$ believe ${ }_{1 \mathrm{SG} . \mathrm{PRES}}$ Jesus $_{\mathrm{ACC}}$ 'because I believe in Jesus' (Wb. $1^{\mathrm{a}} 2$ )
b. hore pridchim soscele do gentib because preach $_{1 \mathrm{SG} . \mathrm{PRES}}$ gospel $_{\mathrm{ACC}}$ to Gentile $\mathrm{DAT}_{\mathrm{DAL}}$ 'because I preach (the) gospel to the Gentiles' (Wb. $5^{\mathrm{c}} 6$ )

The variation between Classes A/B and C for infixed pronouns of whichever person in the syntactic structures mentioned in Group II is to be accounted for as a part of the same variation which is observed in verbal complexes without infixed pronoun. The pair of glosses in (4) shows the variation between declarative and relative third person singular neuter forms in a verbal complex after

5 According to the general definition provided in the works quoted in García-Castillero (2018: 48-49), a "light head" is a demonstrative pronoun which is (more or less exclusively) used as the head of a relative clause. 
(h)óre 'because'. In (4a), we have a Class C infix in the perfect form of as.beir 'says' (to be analyzed as as-ind-rubartatar). In (4b), the perfect form fritracatar, from the verb fris-accai 'hopes for', shows the Class B infixed form which characterises it as a declarative clause type form. This sort of variation is more frequent with non-third persons, a nice example being the gloss in (5), which has a verb with a Class $\mathrm{C}$ form (i.e. no-n-dob-molor-sa, from the simple molaithir 'praises') coordinated with another verbal complex including a Class A infixed form (i.e. no-m·móidim, from the simple moidid 'boasts'), both depending on the previous hore, again the syntactic structure of type (e) above.
a. [...] huare
asinrubartatar
tris pueri
because $\quad$ PV- ${ }^{\mathrm{NAS}_{3}} 3 \mathrm{SG}_{\mathrm{NEUT}}(\mathrm{C}) \cdot \mathrm{Say}_{\mathrm{AUG} .3 \mathrm{PL} . \mathrm{PRET}}$ three children $_{\text {NOM.PL }}$ '[. . . ] because tres pueri had said it' $\left(\mathrm{Ml} .131^{\mathrm{d}} 12\right)$
b. [...] huare fritracatar som a deo because $\quad$ PV-3SG $\mathrm{NEUT}_{\mathrm{N}}(\mathrm{B}) \cdot$ hope $_{\mathrm{AUG} .3 \mathrm{PL} . \mathrm{PRET}}=3 \mathrm{SG}_{\mathrm{NEUT}}$ from $\mathrm{God}_{\mathrm{ABL}}$ '[. . . ] because they have hoped for it a deo' (Ml. 131 $\left.{ }^{\mathrm{C}} 10\right)$
(5) hore nondobmolorsa et nom móidim indib because PV- ${ }^{\mathrm{NAS}} 2 \mathrm{PL}(\mathrm{C}) \cdot$ praise $_{1 \mathrm{SG} . \mathrm{PRES}}=1 \mathrm{SG}$ and $\mathrm{PV}-1 \mathrm{SG}(\mathrm{A}) \cdot$ boast $_{1 \mathrm{SG} . \mathrm{PRES}}$ in $_{2 \mathrm{PL}}$ 'because I praise you and boast myself in you' (Wb. $\left.14^{\mathrm{C}} 18\right)$

The important aspect at this moment is that non-third person infixed pronouns of Class A (i.e. infixed pronouns which value as declarative clause type markers) appear even in subordinate clauses included in Group III of the above classification, that is to say, in syntactic contexts in which relative morphology is consistently used. This can be observed in (6) and (7) with verbal complexes which have the conjunct particle no- and a $\mathrm{CV}$ - lexical preverb respectively. Both cases of (6) involve the same syntactic structure, i.e. a cleft sentence with anteposed subject, i.e. type (g) of Group III: example (6a) uses the expected Class C form -don- in nodonnertani, from the simple nertaid, but example (6b) shows Class A - $m$ - in the simple beoigidir. The morphosyntactic structure in (7) corresponds to type (h) of Group III, i.e. the verbal complex introduced by the conjunction $a^{\mathrm{N}}$ 'when', and (7a) shows the expected Class C form -dat- in afundatferai, from fo-fera, whereas the form in (7b) has the Class A form - $m$ - in andumsennat, from do seinn.
(6) a. is
hé nodonnertani
be $_{3 \mathrm{SG} . \mathrm{PRES}}$ he PV-1PL(c).strengthen 3SG.PRES $=1 \mathrm{PL}$
'It is He that strengthens us.' (Wb. $6{ }^{\mathrm{d}} 11$ ) 
$\begin{array}{llll}\text { b. is iress crist nombeoigedar } & \text { nor } \\ \text { be }_{\text {3SG.PRES }} & \text { faith }_{\mathrm{NOM}} & \text { Christ }_{\text {GEN }} & \text { PV-1SG(A).quicken } \\ \text { 3SG.PRES }\end{array}$

'It is Christ's faith that quickens me.' (Wb. 19²0)

(7) a. afundatferai

when-PV- ${ }^{\mathrm{NAS}}{ }_{2 \mathrm{SG}}(\mathrm{c}) \cdot$ present $_{\text {2SG.PRES }}$

'when you (sg) present yourself (sg)' (Ml. 38' 26-27)

b. andumsennat

when ${ }^{\mathrm{NAS}} \mathrm{PV}-1 \mathrm{SG}(\mathrm{C}) \cdot$ pursue $_{3 \text { PL.PRES }}$

'when they pursue me' (Ml. 39²8)

Even though it is far from being usual, because the 'expected' use of Class C is also frequently encountered in those types included in Groups II and III, the use of Class A instead of Class C is a well-established fact. ${ }^{6}$ The extent to which non-third person infixed pronouns of Class B are used instead of the expected Class C form, that is to say, cases that run parallel to those in (6b) and (7b), is discussed in the next section.

\section{The descriptive problem: The opposition between Class B and Class C}

In contrast to what can be observed for the cases in which the forms of Class A are involved, the use of non-third person infixed pronouns of Class B instead of the Class $C$ counterparts seems to be the rule. The list of forms included in Table 3 below is based on the collection provided by Sommer (1897) and has been revised with the aid of Kavanagh (2001), Griffith and Stifter (2013) and Bauer (2015).

Table 3 is to be interpreted in the following way: the dictionary headword of the Old Irish verb is given in the leftmost column, the attested form and relevant syntactic structure with its English translation appear in the central column, and the following three columns to the right, headed by the signs (I), (II) and (III), correspond to the three main groups of syntactic structures considered in the previous section. In each of the rightmost columns, the following

6 Of the 77 verbal complexes with a non-third person infix attested in Wb., Ml. and Sg. with a pretonic CV- lexical preverb or with a conjunct particle appearing in a syntactic context of Group III, i.e. cases such as those in (6) and (7), 33 cases bear Class A, i.e. 43\%, e.g. (6b) and (7b), and 44 cases bear Class C forms, i.e. $57 \%$, e.g. (6a) and (7a). 
Table 3: Old Irish 1st and 2nd person infixes of Classes B and C in their syntactic context.

\begin{tabular}{|c|c|c|c|c|}
\hline Lemma form & Attested form & $\mathbf{I}$ & II & III \\
\hline \multirow[t]{2}{*}{ as·beir 'says' } & amal asndonberat 'as they say of us' (Wb. $\left.2^{\mathrm{a}} 12\right)$ & & $\mathrm{C}(\mathrm{e})$ & \\
\hline & $\begin{array}{l}\text { (plebs dei) asndanberthe } n i \text { 'It is plebs Dei that } \\
\text { we used to be called.' (Ml. } 114^{\mathrm{a}} 7 \text { ) }\end{array}$ & & & C (g) \\
\hline $\begin{array}{l}\text { as.rochoili } \\
\text { 'determines' }\end{array}$ & $\begin{array}{l}\text { atamrochoilse 'Determine me!' (impv.) } \\
\left.\text { (MI. 24 }{ }^{\mathrm{a}} 15\right)\end{array}$ & B (a) & & \\
\hline $\begin{array}{l}\text { as.scarta 'drives } \\
\text { away' }\end{array}$ & $\begin{array}{l}\text { ma atamscartisse 'if they were to drive me' } \\
\left(\mathrm{MI} .59^{\mathrm{a}} 21\right)\end{array}$ & $B(c)$ & & \\
\hline \multirow[t]{2}{*}{ con·airléici 'permits' } & $\begin{array}{l}\text { condammairleicea 'that He should let me' } \\
\left.\text { (MI. } 38^{\mathrm{a}} 11\right)\end{array}$ & & $C(d)$ & \\
\hline & $\begin{array}{l}\text { iarsindi cotanrairlic 'after He let us go' } \\
\left(\mathrm{MI.} 125^{\mathrm{a}} 9\right)\end{array}$ & & $B(e)$ & \\
\hline $\begin{array}{l}\text { con·boing } \\
\text { 'smashes' }\end{array}$ & $\begin{array}{l}\text { cochotabosadsi 'so that he should crush you' } \\
\left.\text { (Ml. } 18^{\mathrm{a}} 7\right)\end{array}$ & $B(c)$ & & \\
\hline con·delca 'compares' & $\begin{array}{l}\text { frinn fanisin cotondelcfam 'with ourselves we } \\
\left.\text { will compare ourselves' (Wb. } 17^{\mathrm{b}} 10\right)\end{array}$ & $B(b)$ & & \\
\hline $\begin{array}{l}\text { con·éicnigethar } \\
\text { 'compels' }\end{array}$ & $\begin{array}{l}\text { ithéside cotammeignigthersa 'It is these by } \\
\left.\text { which I am compelled.' (MI. } 21^{\mathrm{b}} 10\right)\end{array}$ & $B(b) ?$ & & $\mathrm{~B}(\mathrm{~g})$ ? \\
\hline con·erchloi 'leads' & cotomerchloither 'I am led.' (Sg. 17 7 7), gl. agor & B (a) & & \\
\hline $\begin{array}{l}\text { con·nerta } \\
\text { 'strengthens' }\end{array}$ & $\begin{array}{l}\text { cototnertsu 'Strengthen thyself!' (impv.) } \\
\left(\text { Wb. } 30^{\mathrm{a}} 9\right)\end{array}$ & B (a) & & \\
\hline \multirow[t]{2}{*}{$\begin{array}{l}\text { con·ocaib 'lifts up, } \\
\text { raises' }\end{array}$} & $\begin{array}{l}\text { an condammucbaitisse 'when they used to } \\
\left.\text { beatify me' (Ml. } 39^{\mathrm{d}} 11\right)\end{array}$ & & & $C(h)$ \\
\hline & cotabucabarsi ‘Be lifted up!’ (impv.) (Ml. 46ª 7 ) & B (a) & & \\
\hline \multirow[t]{3}{*}{ con·oscaigi 'moves' } & $\begin{array}{l}\text { cotammoscaigse 'I should move [in the } \\
\text { mountains].' (MI. 29d } 3 \text { ) }\end{array}$ & B (a) & & \\
\hline & $\begin{array}{l}\text { condatoscaigther 'that you might be moved' } \\
\left(\text { Ml. } 23^{\text {d }} 21\right) \text {, gl. commouere }\end{array}$ & & $C(d)$ & \\
\hline & $\begin{array}{l}\text { cotatoscaigthersu ‘Be moved, O God!' (impv.) } \\
\text { (Ml. 58 }{ }^{\mathrm{d}} 14 \text { ) }\end{array}$ & B (a) & & \\
\hline \multirow[t]{2}{*}{ con.rig 'binds' } & cotobárrig '[he] has constrained you' (Wb. 9 19 ) & B (a) & & \\
\hline & cotanrirastarni 'We will be bound.' (ML. 134ª 1 ) & B (a) & & \\
\hline con·secha 'corrects' & cotob sechfider 'Ye will be corrected.' (Wb. 9²3) & B (a) & & \\
\hline
\end{tabular}


Table 3 (continued)

\begin{tabular}{|c|c|c|c|c|}
\hline Lemma form & Attested form & $\mathbf{I}$ & II & III \\
\hline con·utuinc 'builds' & $\begin{array}{l}\text { cotofutaincsi (MS cotofutaircsi) 'He upbuilds } \\
\left.\text { you.' (Wb. } 8^{c} 16\right)\end{array}$ & B (a) & & \\
\hline in.árban 'impels' & $\begin{array}{l}\text { atataírbined su 'Let it impel You.' (impv.) } \\
\left.\text { (Ml. } 86^{\mathrm{C}} 10\right)\end{array}$ & B (a) & & \\
\hline \multirow{3}{*}{$\begin{array}{l}\text { in·greinn } \\
\text { 'persecutes' }\end{array}$} & atamgrennat 'They persecute me.' (ML. 39 ${ }^{\mathrm{d}} 13$ ) & $B(a)$ & & \\
\hline & $\begin{array}{l}\text { donaib hi atamgrennat 'to those who persecute } \\
\left.\text { me' (Ml. } 127^{c} 8\right)\end{array}$ & & & $B(f)$ \\
\hline & $\begin{array}{l}\text { honaib hí atangrennat 'by those who persecute } \\
\left.\text { us' (Ml. } 45^{\mathrm{a}} 16\right)\end{array}$ & & & $B(f)$ \\
\hline $\begin{array}{l}\text { ind·saig }(/ \text { ad·saig) } \\
\text { 'approaches' }\end{array}$ & $\begin{array}{l}\text { frisna preceptori atobsegatsi 'like the preachers } \\
\left.\text { who go to you' (Wb. } 14^{\mathrm{d}} 37\right)\end{array}$ & & & $B(f)$ \\
\hline in.snaid 'inserts' & $\begin{array}{l}\text { coatomsnassar 'that I may be engrafted' } \\
\left(\text { Wb. } 5^{\text {b }} 30\right) \text {, gl. ut ego inserer }\end{array}$ & $B(c)$ & & \\
\hline $\begin{array}{l}\text { in.sorchaigedar } \\
\text { 'illuminates' }\end{array}$ & $\begin{array}{l}\text { coatabsorchaigther (MS coatabsorchaither) } \\
\left.\text { 'that you may be illuminated' (MI. } 53^{\text {b}} 15\right)\end{array}$ & $B(c)$ & & \\
\hline in·togair 'invokes' & $\begin{array}{l}\left.\text { indattogarsa 'that I invoke you' (MI. } 72^{\mathrm{c}} 4\right) \text {, } \\
\text { gl. inuocandi te }\end{array}$ & & $C(d)$ & \\
\hline \multirow[t]{5}{*}{ ad·aig 'drives' } & $\begin{array}{l}\text { massuthol atomaig 'if it is desire what drives } \\
\text { me' (Wb. 10 } 26)\end{array}$ & & & $\mathrm{B}(\mathrm{g})$ \\
\hline & $\begin{array}{l}\text { dílmaine aisndisen atannaigni 'Licence of } \\
\left.\text { narration impels us.' (ML. } 93^{\mathrm{d}} 12\right)\end{array}$ & $B(a) ?$ & & $\mathrm{~B}(\mathrm{~g})$ ? \\
\hline & $\begin{array}{l}\text { isfoirbthetu hirisse attotaig 'It is perfection of } \\
\left.\text { faith that impels thee.' (ML. } 93^{\mathrm{d}} 12\right)\end{array}$ & & & $\mathrm{B}(\mathrm{g})$ \\
\hline & cid atobaich 'What impels you?' (Wb. $\left.9^{\mathrm{c}} 20\right)$ & & & B (i) \\
\hline & $\begin{array}{l}\text { cid atobaig dó 'What impels you to it?' } \\
\text { (Wb. 19 10a) }\end{array}$ & & & B (i) \\
\hline ad·anaig 'brings' & $\begin{array}{l}\text { atomanaste 'that I should be brought' } \\
\left(\text { Wb. } 14^{\mathrm{c}} 20\right) \text {, gl. a uobis deduci }\end{array}$ & & $B(d)$ & \\
\hline \multirow[t]{2}{*}{ ad.cí ‘sees' } & atatchigestar 'You will be seen.' (Ml. 59 $\left.9^{c} 12\right)$ & B (a) & & \\
\hline & atobcíside 'He perceives you,' (Wb. 25 $\left.{ }^{\mathrm{a}} 26\right)$ & B (a) & & \\
\hline $\begin{array}{l}\text { ad·cumaing } \\
\text { 'happens' }\end{array}$ & $\begin{array}{l}\text { cindas persine attotchomnicc 'What sort of } \\
\text { person art thou' (lit. 'what sort of person is it } \\
\left.\text { that has befallen you?') (Wb. } 6^{b} 13\right)\end{array}$ & & & $B(f)$ \\
\hline
\end{tabular}


Table 3 (continued)

\begin{tabular}{|c|c|c|c|c|}
\hline Lemma form & Attested form & $\mathbf{I}$ & II & III \\
\hline ad.ella 'visits' & atdubelliub 'I will visit you.' (Wb. $\left.7^{\mathrm{a}} 4\right)$ & B (a) & & \\
\hline ad·eirrig 'emends' & $\begin{array}{l}\text { atanneirrig 'who emends us' }\left(\mathrm{Ml} .114^{\mathrm{d}} 10\right) \text {, } \\
\text { gl. qui nos [. . .] emendat }{ }^{10}\end{array}$ & & & $B(f)$ \\
\hline $\begin{array}{l}\text { ad.gaib } \\
\text { 'reprehends' }\end{array}$ & $\begin{array}{l}\text { atabgabed 'Let it reprehend you (pl).' (impv.) } \\
\left(\mathrm{MI} .20^{\mathrm{d}} 11\right)\end{array}$ & B (a) & & \\
\hline $\begin{array}{l}\text { ad·gair 'sues, } \\
\text { forbids, fascinates' }\end{array}$ & $\begin{array}{l}\text { adobragart ' 'He sued you.' (Wb. } 19^{\mathrm{b}} 5 \text { [prima } \\
\text { manus]), gl. uos fascinavit }\end{array}$ & B (a) & & \\
\hline $\begin{array}{l}\text { ad.gládathar } \\
\text { 'addresses' }\end{array}$ & $\begin{array}{l}\text { lase atat gladainn se 'when I used to address } \\
\left.\text { you' (MI. } 62^{\mathrm{C}} 16 .\right)\end{array}$ & & $\mathrm{B}(\mathrm{e})$ & \\
\hline ad.gnin 'recognizes' & atatgentarsu 'You will be known.' (Ml. $\left.121^{\mathrm{d}} 22\right)$ & $B(a)$ & & \\
\hline ad.indnaig 'leads' & $\begin{array}{l}\text { atdomindnastar in ispaniam 'I shall be brought } \\
\left.\text { in Hispaniam.' (Wb. } 7^{\mathrm{a}} 5\right)\end{array}$ & $B(a) ?$ & $B(d) ?$ & \\
\hline ad·opair 'sacrifices' & atamroipred 'I was offered.' (MI. 44'17) & B (a) & & \\
\hline at.reig 'rises' & anatammresa 'when I will rise' (MI. 31'14) & & & $B(h)$ \\
\hline \multirow[t]{6}{*}{ fris·oirg 'injures' } & $\begin{array}{l}\text { fritumchomartsa 'I have been offended.' } \\
\left(\text { Wb. } 33^{\mathrm{a}} 12\right)\end{array}$ & B (a) & & \\
\hline & $\begin{array}{l}\text { cia erat fritammior sa 'How long will it afflict } \\
\left.\text { me?' (Ml. } 32^{\mathrm{d}} 27\right)\end{array}$ & & & $B(f) ?$ \\
\hline & $\begin{array}{l}\text { is ed aerat fritammiurat '[lt is] so long [that] will } \\
\left.\text { they afflict me.' (Ml. } 33^{\mathrm{a}} 1\right)\end{array}$ & & & $B(f)$ \\
\hline & fritammorcat 'who injure me' (MI. 39² 27$)$ & & & $B(f)$ \\
\hline & $\begin{array}{l}\text { cum }^{8} \text { fritammoircise 'when you injure me' } \\
\text { (Ml. } 44^{\text {b } 26)}\end{array}$ & & & $\mathrm{B}(\mathrm{e})$ \\
\hline & $\begin{array}{l}\text { frisnahi fritammorcat sa 'against those that } \\
\left.\text { afflict me' (ML. } 62^{\mathrm{C}} 21\right)\end{array}$ & & & $B(f)$ \\
\hline
\end{tabular}

7 Sommer (1897: 190) is probably right when he explains this form as due to a mistake of the glossator ("Wohl Versehen des Schreibers für atob- [probably a mistake of the scribe for atob-]"). 8 Stokes and Strachan (1901-1910 = Thes. 1: 126, n. m) note that this Latin conjunction stands for Old Irish intan 'when' or lase ‘while'. 
Table 3 (continued)

\begin{tabular}{|c|c|c|c|c|}
\hline Lemma form & Attested form & $\mathbf{I}$ & II & III \\
\hline & $\begin{array}{l}\text { ciofut fritatniarrsu 'How long will he offend } \\
\text { You?' (ML. 93 } 15 \text { ) }\end{array}$ & & & $B(f)$ \\
\hline fris·tét 'answers' & $\begin{array}{l}\text { fritumthiagar 'I am answered.' (Sg. 183 } 3 \text { ), } \\
\text { gl. obeor }\end{array}$ & B (a) & & \\
\hline $\begin{array}{l}\text { for } \cdot \text { brissi 'breaks } \\
\text { down' }\end{array}$ & $\begin{array}{l}\text { sechnicoimnactar arnamait són fortanbristis ni } \\
\text { 'That is, our enemies have not been able to } \\
\left.\text { crush us.' (Ml. } 135^{\text {d }} 4\right)\end{array}$ & & $B(d)$ & \\
\hline \multirow[t]{6}{*}{ for-cain 'teaches' } & $\begin{array}{l}\text { isdo fordoncain 'It is for this it teaches us.' } \\
\text { (Wb. 31'16) }\end{array}$ & $\mathrm{B} ?(\mathrm{~b})$ & & \\
\hline & fortanroichanni 'You have instructed us' (MI. 22 ${ }^{\mathrm{C}} 3$ ) & $B(a)$ & & \\
\hline & $\begin{array}{l}\text { it [hé] fortan roichechnatarni 'It is they that } \\
\left.\text { taught us.' (Ml. } 63^{\mathrm{b}} 1\right)\end{array}$ & & & $B(g)$ \\
\hline & $\begin{array}{l}\text { aforcital forndobcanar 'the teaching by which ye } \\
\text { are taught' (Wb. } 3^{\text {b } 23) ~}\end{array}$ & & & $C(f)$ \\
\hline & $\begin{array}{l}\text { fortab cech ansa 'I will teach you (pl.).' (MI. } \\
\left.53^{\mathrm{C}} 14\right)\end{array}$ & $\mathrm{B}(\mathrm{a})$ ? & & \\
\hline & $\begin{array}{l}\left.\text { fordubcechna 'who shall teach you' (Wb. } 9^{\mathrm{a}} 16\right) \text {, } \\
\text { gl. qui uos commonefaciat }\end{array}$ & & & $C ?(\mathrm{f})$ \\
\hline $\begin{array}{l}\text { for-diuclainn } \\
\text { 'devours' }\end{array}$ & $\begin{array}{l}\text { fortamdiucuilset sa 'that they may devour me' } \\
\text { (Ml. } 44^{\mathrm{C}} 32 \text { ), gl. uorare me }\end{array}$ & & $B(d) ?$ & \\
\hline $\begin{array}{l}\text { for.comai } \\
\text { 'preserves' }\end{array}$ & fordomchomaither 'I am preserved.’ (Sg. 139 2 2) & B?(a) & & \\
\hline $\begin{array}{l}\text { for.moinethar } \\
\text { 'envies' }\end{array}$ & fordobmoinetar 'They envy you.' (Wb. $\left.19^{\mathrm{d}} 27\right)$ & B?(a) & & \\
\hline \multirow[t]{2}{*}{ for-tét 'helps' } & $\begin{array}{l}\text { cofardumthésidse 'so that you may help me' } \\
\text { (Wb. } 7^{\mathrm{a} 12} \text { ) }\end{array}$ & $B ?(c)$ & & \\
\hline & fortat tet su 'It helps you.' (MI. 43 $\left.{ }^{\mathrm{b}} 11\right)$ & $B(a)$ & & \\
\hline \multirow[t]{2}{*}{$\begin{array}{l}\text { etar.díben } \\
\text { 'destroys' }\end{array}$} & $\begin{array}{l}\text { co etardamdibet sa 'in order that they might } \\
\left.\text { destroy me' (Ml. } 44^{\mathrm{c}} 31\right)\end{array}$ & $\mathrm{B} ?(\mathrm{c})$ & & \\
\hline & $\begin{array}{l}\text { co etardamdibitisse 'in order that they might } \\
\left.\text { destroy me' (Ml. } 54^{\mathrm{d}} 14\right)\end{array}$ & $B ?(c)$ & & \\
\hline $\begin{array}{l}\text { etar.scara } \\
\text { 'separates' }\end{array}$ & $\begin{array}{l}\text { lasse etardanroscarni 'when he has separated } \\
\left.\text { us' (MI. } 120^{\mathrm{a}} 3\right)\end{array}$ & & $\mathrm{C} ?(\mathrm{e})$ & \\
\hline
\end{tabular}


information is encoded: the capital letters B and C refer to the infix class used, and the small letter between parentheses indicates the syntactic structure in which it is used. Bearing in mind the possibility of having a declarative instead of a relative verbal form observed in the previous section, the information encoded in those three columns must be read as follows. The presence of B in column (I) is the expected procedure in the syntactic structures concerned. The presence of $\mathrm{B}$ or $\mathrm{C}$ in column (II) can be considered as a part of the general phenomenon of variation between declarative and relative clause type forms in those syntactic environments. Finally, in column (III), i.e. in the syntactic environments in which relative morphology (in this case, Class $\mathrm{C}$ of pronominal infix) is expected, the presence of a Class B form should be considered as parallel to the use of Class A in those situations, as illustrated in examples (6b) and (7b) of the previous section. The question mark after the capital letter indicates that the infix Class (either B or C) is not clear, something which is not rare at all. After the letter between parentheses, the question mark indicates that the syntactic structure involved is not clear. Note also that imperative forms (e.g. the form of the verb as.rochoili) are marked as (a), i.e. they are counted along with the declarative forms.

The descriptive problem posed by the forms included in Table 3 is the considerably high amount of Class B non-third person infixes in verbal forms in which relative morphology is expected. To be more precise, in the syntactic structures of Group III, this is the case of 19 cases out of a total of 23 forms; this $80 \%$ of unexpected Class B contrasts with the $43 \%$ of unexpected Class A observed at the end of the previous section.

The evidence provided by the Old Irish glosses, as it is presented in Table 3, permits us to make finer distinctions, in this case, according to the lexical preverb involved. The verbs in Table 3 are ordered according to whether they distinguish between Classes $\mathrm{B}$ and $\mathrm{C}$, such that those lexical compounds which distinguish (more or less frequently) between the two classes precede those which apparently do not. Thus, a fairly frequent verb with the lexical preverb assuch as as·beir 'says' uses on two occassions the Class C forms of the non-third persons infixed pronouns, the reason being probably the nasalising character of the relative forms involved. In the case of the preverb con-, one out of three cases of forms in which relative morphology (i.e. Class $\mathrm{C}$ ) would be expected shows the form used as Class B. The verbal forms with the preverb in $(d)$ - show only one case of Class $\mathrm{C}$ infixed pronoun out of four possible forms. The preverbs ad-and fris- only display Class B forms, regardless of the expected clause type morphology. Finally, the preverbs for- and etar- also show a considerable degree of confusion between the spellings with $t$ and $d$. On the one hand, the forms spelt with -t- can be identified as Class B infixes, but some of them (e.g. fortan 
roichechnatarni 'who have taught us') appear in forms in which relative morphology would be expected, whereas the forms with - $d$-, which therefore seem to be Class $C$ forms, appear in syntactic environments in which declarative morphology is undoubtedly expected (i.e. co etardamdibet $s a$ 'in order that they might destroy me'). As usually acknowledged, the spellings $-t$ - and $-d$ seem to interchange freely in the cases in which these two preverbs in pretonic position are combined with a pronominal infix.

The conclusion seems plausible that non-third persons actually are on the verge of making no distinction between Classes $\mathrm{B}$ and $\mathrm{C}$, that is to say, that a good deal of the compounds with preverbs of the type (-)VC- only use one set of non-third person infixed pronouns, regardless of the expected declarative or relative morphology of the verb. The descriptive problem may therefore be formulated in terms of paradigm defectiveness: is the opposition between Classes $\mathrm{B}$ and $\mathrm{C}$ an actually effective opposition in the non-third persons, so that the rare cases in which an apparently Class $\mathrm{C}$ form may be identified are actually a sort of incipient attempt to establish that distinction?

In this descriptive problem it is not convenient to take for granted the existence of a specific differentiation in a particular NP type (in this case, first and second person pronouns) by the mere fact that that differentiation is carried through in other types of NPs (in this case, third person pronouns). The former constitutes a natural class which may show specific inflectional features not observable in the latter. Witness the various cases of lack of formal expression observable in the first and second pronominal elements of not a few ancient Indo-European languages for a grammatical opposition which is formally marked in the remaining NPs, as detailed in García-Castillero (2001). In itself, the assumption of such an asymmetric situation between non-third and third person pronominal markers would not be something objectable.

The position defended in this paper is that such an asymmetric paradigm in the infixed pronouns attached to (-)VC- lexical preverbs (with the exception of imm- and $a r$-) must be taken seriously, so that the differentiation between relative and declarative forms is more or less systematic for the third persons, but not for the non-third persons. Table 4 below can be viewed as a complement of Table 2 above as a means of representing more realistically the situation of the (-)VC- lexical preverbs other than con- and in-, i.e. the situation of for-, etar-, fris-, and ad-, which do not distinguish systematically between $\mathrm{B}$ and C Classes of non-third person infixed pronouns. 
Table 4: The lexical preverbs to- (representing CV-) and for(representing (-)VC- preverbs) and the use of Classes A, B and C of infixed pronouns in the language of the Old Irish glosses.

\begin{tabular}{|c|c|c|c|c|}
\hline & Class A & Class B & Class C & Class C \\
\hline & to- & for- & & to- \\
\hline $1 \mathrm{sg}$. & do- $m-^{\mathrm{L}}$ & for-t/dam ${ }^{\mathrm{L}}$ & & do-dam ${ }^{\mathrm{L}}$ \\
\hline $2 \mathrm{sg}$. & do-t ${ }^{\mathrm{L}}$ & for-t/dat ${ }^{\mathrm{L}}$ & & do-dat- ${ }^{\mathrm{L}}$ \\
\hline 3sg.masc. & $d(o)-a^{-\mathrm{N}}$ & for- $t^{-}{ }^{\mathrm{N}}$ & for-id ${ }^{\mathrm{N}}$ & $d o-d^{\mathrm{N}}$ \\
\hline 3sg.neut. & $d(0)-a^{-}{ }^{\mathrm{L}}$ & for-t ${ }^{\mathrm{L}}$ & for-id- ${ }^{\mathrm{L}}$ & $d o-d-^{\mathrm{L}}$ \\
\hline 3sg.fem. & do-s- & for- $t / d a-$ & & do-da- \\
\hline $1 \mathrm{pl}$. & do-n- & for-t/dan- & & do-dan- \\
\hline $2 \mathrm{pl}$. & $d o-b-$ & for-t/dab- & & do-dab- \\
\hline $3 p l$. & $d o-s-{ }^{N}$ & for- $t / d a^{-\mathrm{N}}$ & & $d o-d a-{ }^{\mathrm{N}}$ \\
\hline
\end{tabular}

\section{The diachronic problem: Paradigmatic split or merger?}

Up to this point, the diachronic perspective has been adopted only on a couple of occasions to consider the morphological processes leading to the formation of some Class A infixed pronouns, side by side with a more descriptive account of the same phenomenon. This section introduces the systematic consideration of the origin of the Class B forms, for which a purely descriptive stance has hitherto been adopted.

Whereas Class B clearly represents a problem in this regard, there is great consensus (if not complete agreement) among scholars about the etymology of the Old Irish Classes A and $\mathrm{C}$ of infixed pronouns.

To begin with Class $C$, the $-d$ - of this set of forms is etymologically the same element as the - $d$ - of the negative relative conjunct particle nad-mentioned in section 2 above. Especially in the case of the first and second persons, the Class $\mathrm{C}$ forms can be analysed straightforwardly as the combination of that - $d$ - with the corresponding infix of Class A: e.g. Class $C$ first person singular -dom- equals ${ }^{\star}-d(V)-+$ Class A first person singular $-m$ - and so on. For the ultimate (i.e. Proto-IndoEuropean) origin of this Old Irish $-d$ - marker associated to relative clause type 
marking, namely, the connective clitic * $d e$, I refer to the observations and references in Watkins (1963: 24) and McCone (2006: 273-276).

As for the Class A forms, I focus on the third person singular masculine / neuter infix(es), which will play an important role in the next section. It is usually assumed that they represent the clitic accusative masculine and neuter forms of the Proto-Indo-European anaphoric stem ${ }^{\star} e / i$, namely, the forms ${ }^{\star} e m$ and ${ }^{\star} e d$ respectively. For these Proto-Irish and Proto-Insular Celtic forms, see Schrijver (1997b: 54-56). Assuming that the dental plosive of the neuter form was lost in absolute final position, the resulting forms ${ }^{\star} e m$ and ( $e d>$ ) ${ }^{\star} e$ explain the nasalising and leniting effects of the corresponding infixes in Old Irish, which have been noted as $-a^{-}{ }^{\mathrm{N} / \mathrm{L}}$. As for the combination with the lexical preverbs with the shape CV-, the process assumed in section 3.3 which involves the elimination of the first of two vowels standing in hiatus seems to be the best diachronic explanation for these forms. This diachronic origin is perfectly compatible with the synchronic interpretation in terms of replacive morphology, as also stated in section 3.3.

It is also worth noting in this section that the exceptional character of the Old Irish lexical preverbs imm- and ar- is due to the fact that they come from forms which originally ended in a vowel (see GOI §411). This original vocalic auslaut agrees with or directly explains (a) the use of Class A infixed pronouns with the lexical preverbs imm- and ar- as observed in Table 2 above, (b) the relative clause type forms with these lexical preverbs (i.e. imme/a- and are/a-), as well as (c) the palatal character of the preverb ar- in the tonic position of the prototonic forms. ${ }^{9}$

The preverb noted in Table 1 as *ath(i), which appears as aith- 're-' in its stressed form, and as ad- in the pretonic position, takes Class B infixes and must be assumed, at least for the form used in pretonic position, as a preverb without the final vowel, in spite of its most probable etymology, which has a final vowel. In order to explain the different behaviour of this *ath(i) with respect to ar- and imm-, Uhlich (2009-2010: 154) adduces that the former lacks a prepositional counterpart as the reason for the maintenance of the form without vowel *ath- > Old Irish ad- 're-'. The lexical preverbs imm- and ar- had a

9 Consider e.g. the imperative airbir (biuth) 'consume!' (Wb. 29²5), from ar.beir, where the stress falls on the first vowel of the preverb; similarly, nádairchissa 'that he spare not' (Wb. $5^{\mathrm{b}} 35$ ), a present subjunctive from the verb ar.cessi. In forms like these, the original shape of the preverb may have been both *-are- and *-ari-. I leave this question of the original auslaut of Old Irish ar- open. 
prepositional counterpart, in which Uhlich assumes that the final vowel would have been maintained and therefrom extended to the preverb. ${ }^{10}$

A clear consequence of this diachronic observation on imm-and ar-is that the phonotactic structure of the lexical preverb involved must be taken as the definitive factor deciding the Class (whether A or B) of the infixed pronoun used to express declarative clause type. In order to include ar- and imm-, the shape hitherto considered as CV- should be reformulated as * $(\mathrm{V}) \mathrm{CV}$-, as (*-)CVor, more simply, as (-)CV-. This is an important argument to be considered in the diachronic discussion in this section, but is not the explanation itself, since it still does not state the reason for the use of Class B infixes after lexical preverbs of the shape (-)VC-.

As for Class B infixed pronouns, and in line with the descriptive question formulated in the previous section, the diachronic problem can be formulated as follows: is the virtual lack of distinction between Classes B and C in the nonthird persons a remnant of an original situation in which there was actually no such distinction, or is it the outcome of a process in which two originally different paradigms (Classes B and C) are not distinguished anymore, or only scarcely, in the non-third persons? In other words, one must decide between a process of paradigmatic split or a process of paradigmatic merger, respectively.

The diachronic explanation to be developed in the next section assumes that there was originally a single paradigm of forms and that a process of morphological split has given rise to two forms for some elements of the paradigm, in this case, in the third persons, and tentatively in the other persons and for some lexical preverbs.

The opposite view has also been defended, most conspicuously perhaps by Thurneysen (GOI §455), who relies on the form adopted by the (-)VC- preverbs con- and in $(d)$ - in the expression of Class B pronominal infixes. Certainly, cotand at- can be the phonologically regular outcome of previous sequences such as ${ }^{\star} k o n-t$ - and ${ }^{*}$ in- $t$ - respectively. On the basis of these forms, Thurneysen assumes that Class B is initially the form of the Proto-Indo-European demonstrative stem ${ }^{\star}$ so-/to-, which was initially used to express some third persons, and was later generalised for the remaining persons. The main problem this assumption faces is that it completely lacks a motivation for the use of two different infixes, say, the acc.sg. masc. ${ }^{\star} e m$ (from the PIE stem ${ }^{\star} e / i$ ) ) as the forerunner of the third

10 Though it is certainly difficult to demonstrate, it may well be the case that aith- / ad- 're-', due to the fact that it is less frequent than ar- and imm- and also due to its formal similarity with ad- (in line with the argument in section 3.3 on the loss of formal distinctivity of previously different preverbs, especially in pretonic position), has been secondarily attracted to the group of the (-)VC- lexical preverbs. 
person singular masculine of Class A, and the acc.sg. masc. *tom, as the forerunner of the corresponding form of Class B. Since the distribution of Classes A and $B$ is clearly associated to the phonotactic shape of the lexical preverb involved in the pretonic position, as just stated, one should ask why a lexical preverb such as, say, ${ }^{\star} d i / e$ - took ${ }^{\star}$-em-, whereas forms such as ${ }^{\star} e k s->{ }^{\star} e s s-$ would have taken *-tom- to express the same person in exactly the same syntactic context.

For other proposals for the origin of Class B which are located in a wider discussion but which defend two originally different paradigms, see McCone (2006: 229-231).

\section{The present hypothesis: The paradigmatic split into $B$ and $C$}

This section develops the hypothesis of a paradigmatic split according to which a unique paradigm, the one which is Class $\mathrm{C}$ in Old Irish, split into two different paradigms, Classes $\mathrm{B}$ and $\mathrm{C}$. This explanation has three points: (i) the trigger of the split, dealt with in section 6.1; (ii) the specific syntactic context(s) in which the use of Class $C$ in declarative clause type forms was enabled, in section 6.2; and (iii) the very process of paradigmatic split, in section 6.3.

\subsection{Watkins' (1962) 'Forward Reconstruction' and the trigger of the split}

The starting point of this diachronic explanation is the consideration of the paradigmatic structure in which the $[ \pm$ third person singular masculine / neuter pronominal infixes] feature cross-cuts the declarative vs relative clause type opposition, in line with the second issue considered in section 2 above.

The resulting schema of formal oppositions is illustrated in Table 5 with the lexical compound do.beir 'brings, gives', the lexical preverb of which has the $\mathrm{CV}$ - shape. On the one hand, the declarative and relative forms without infixed pronoun contrast by the lack or presence respectively of relative mutation (nasalisation or lenition) in the first consonant of the tonic part; this is an example of one of the formal strategies in which this clause type opposition is marked. On the other, the contrast between the latter form, i.e. the relative clause type form without pronominal infix, and the declarative form with such an infix is expressed by means of the different vowel of the pretonic preverb, which are - $o$ - and - $a$ - respectively; this difference has been discussed in section 3.3 above. 
Table 5: $[ \pm$ 3rd person singular masculine / neuter pronominal infixes] and the difference declarative vs relative clause type in a lexical compound with a (-)CV- preverb.

\begin{tabular}{lll}
\hline & Declarative clause type & Relative clause type \\
\hline [- 3sg. masc./neut. pronominal infixes] & $\begin{array}{l}\text { do.beir } \\
\text { '(s)he brings' }\end{array}$ & $\begin{array}{l}d o \cdot{ }^{\mathrm{N} / \mathrm{L}} \text { beir } \\
\text { 'who(m) / that ([s]he) brings' }\end{array}$ \\
\hline [+ 3sg. masc./neut. pronominal infixes] & $\begin{array}{l}d a \cdot{ }^{\mathrm{N} / \mathrm{L}} \text { beir } \\
\text { '(s)he brings him / it' }\end{array}$ & $\begin{array}{l}\text { dod. }{ }^{\mathrm{N} / \mathrm{L}} \text { beir }^{11} \\
\text { 'who / that brings him / it' }\end{array}$ \\
\hline
\end{tabular}

The four Old Irish verbal complexes turn out to be formally distinct, subtle and minimal as the difference may be.

The basic diachronic assumption of this proposal is that the Class B of infixed pronouns is the response to a situation in which (some of) the (-)VC- lexical preverbs were not able to make an important distinction, the one between the nasalising and leniting relative forms, on the one hand, and the declarative form including the third person singular masculine / neuter infixed pronouns as initially expected according to the same origin assumable for those infixes in combination with $\mathrm{CV}$ - lexical preverbs (i.e. ${ }^{\star} e m$ and ${ }^{\star} e[d]$ ), on the other. The reason for this formal coincidence was that the latter regularly lost its palatal character ${ }^{12}$ in pretonic position, the only remnant of their presence being nasalisation and lenition. This initial situation is reflected in Table 6, in which the declarative clause type form combined with the third person singular masculine / neuter infixed pronoun (i.e. the form ${ }^{*} a d{ }^{\mathrm{N} / \mathrm{L}} \mathrm{ci}$ ' (s)he sees him / it') is 'forward-reconstructed' in the sense of Watkins (1962: 2-3) and Eska (2003), i.e. is reconstructed as an expected Old Irish form which, however, is not attested. In the same table, the assumed relative form including the corresponding infixed pronoun has the expected outcome for a Class C form, i.e. ${ }^{\star} a t \cdot{ }^{\mathrm{N} / \mathrm{L}} \mathrm{ci} / \mathrm{ad}-/ /$ 'who sees him $/$ it' $<{ }^{\star} a \partial-d e-e(m)$-. This form, which is in Old Irish declarative due to its Class B infixed form, is marked with an asterisk because it is given as a relative form.

As for as-, the form with Class A third person singular masculine / neuter pronominal infix would have been ${ }^{\star} e s^{\mathrm{N} / \mathrm{L}}$ - (cf. the Old Irish conjugated preposition es(s), mostly ass 'out of it'), depalatalised as ${ }^{\star} e s^{\mathrm{N} / \mathrm{L}}$ - and then ${ }^{\star} a s^{\mathrm{N} / \mathrm{L}}-$, in

11 Note that the mutations marked as ${ }^{\mathrm{N} / \mathrm{L}}$ in the forms of this table do not always have the same function: whereas in $d 0^{\mathrm{N} / \mathrm{L}}$ beir they are the relative mutations, in $d a \cdot^{\mathrm{N} / \mathrm{L}}$ beir and $d o d{ }^{\mathrm{N} / \mathrm{L}}$ beir they are the mutations provoked by the third person singular masculine and neuter infixes respectively.

12 This palatal character is the effect of the so-called second or third palatalizations, which assume palatalization by the effect of a vanishing front vowel (McCone 1996: 117,119). 
Table 6: The expected homonymy of declarative form with 3rd person singular masculine / neuter pronominal infixes and relative without such pronominal infix in a lexical compound with preverb (-)VC-.

\begin{tabular}{|c|c|c|}
\hline & Declarative clause type & Relative clause type \\
\hline $\begin{array}{l}\text { [- 3sg. masc./neut. pronominal } \\
\text { infixes] }\end{array}$ & $\begin{array}{l}\text { ad·cí } \\
\text { '(s)he sees' }\end{array}$ & $\begin{array}{l}a d \cdot{ }^{\mathrm{N} / \mathrm{L}} c i ́ \\
\text { 'who(m) / that ([s]he) } \\
\text { sees' }\end{array}$ \\
\hline $\begin{array}{l}\text { [+ 3sg. masc./neut. pronominal } \\
\text { infixes] }\end{array}$ & $\begin{array}{l}\left({ }^{\star} a \partial-e(m)->\right){ }^{*} a \gamma^{\prime}-{ }^{\mathrm{N} / \mathrm{L}}>0 \text { Old Irish } \\
{ }^{*} a d \cdot{ }^{\mathrm{N} / \mathrm{L}} c i \\
\text { '(s)he sees him / it' }\end{array}$ & $\begin{array}{l}{ }^{*} a t^{\mathrm{N} / \mathrm{L}}{ }^{\mathrm{c} i} \\
\text { 'who / that sees } \\
\text { him / it' }\end{array}$ \\
\hline
\end{tabular}

much the same way as most cases of the conjugated preposition just quoted. Other (-)VC lexical preverbs would have evolved as $\left({ }^{\star}\right.$ wor-e $\left.[\mathrm{m}]->\right){ }^{\star}$ foir ${ }^{\mathrm{N} / \mathrm{L}}$ - (by depalatalisation of unstressed forms $>$ Old Irish ${ }^{\star}$ for $\left.{ }^{\mathrm{N} / \mathrm{L}}-\right)$, and $\left({ }^{\star} k o n-e[m]->\right)$ ${ }^{\star} \operatorname{coin}^{\mathrm{N} / \mathrm{L}}$ - (by depalatalisation) $>$ Old Irish ${ }^{\star} \operatorname{con}^{\mathrm{N} / \mathrm{L}}-{ }_{-}^{13}$ In other words, I am assuming here that the palatal character caused by the (Class A) third person singular masculine / neuter infixed pronoun in (-)VC- lexical preverbs would have been lost in pretonic position and that this brought about the complete homonymy of this form and the same lexical preverb followed by relative nasalisation and lenition.

As for the depalatalisation itself, current treatments as e.g. McCone (1996: 135) and Stifter (2009: 62) assume an Early Old Irish process affecting consonants in unstressed words such as the copula, prepositions, particles, etc., and this inevitably implies a relatively recent chronology for the rise of Class B infixed pronouns, not very long before the classical Old Irish period.

The Early Old Irish texts in which some such functional words still show palatal character are the Cambray Homily and the prima manus of the Wb. Glosses, both dated approximately between the end of the seventh and the beginning of the eighth centuries. There is a potential problem in that the Cambray Homily includes a case of Class B pronominal infix, precisely the third person singular neuter form (autrubert 'has said it' [Thes. 2: 246.14], from as.beir). In this sense, one could argue that, if depalatalisation was still a process not accomplished in these Early Old Irish texts, then the creation of the Class B infixed form in the manner just assumed could hardly have happened. However, the

13 The specific situation of the lexical preverb ete/ir- is too complicated to be considered in this paper. 
forms which still show palatalisation are of a different nature to the lexical preverbs of verbal complexes, as is perhaps suggested by Thurneysen (GOI § 168). They are independent conjunctions which still show their original palatal character: amail 'as' (Thes. 2: 245.14) for later amal, oire 'because' (Thes. 2: 246.5-6) for later (h)óre, (h)uare (as in e.g. (3), (4) and (5) above). In the case of these and other conjunctions, the depalatalisation is probably a process to be assumed for later phases, as seems to be the case of intain 'when' (Thes. 2: 247.3), which in Wb. appears mostly as intain and in Ml. and Sg. mostly as intan; or even air 'for' (Thes. 2: 245.33), which later appears both as air, as in example (2a), and as ar. These differences are probably due to the different chronologies of the grammaticalisation processes leading to their character of conjunction, which is probably accompanied by a difference in stress. With respect to the independent conjunction air 'for', the corresponding stressed conjugated form aire 'for him, for it' appears in this manner both in the Cambray Homily (cf. Thes. 2: 244.33) and in classical Old Irish. ${ }^{14}$

None of the unstressed forms quoted in the previous paragraph, however, are constitutive components of the Old Irish verbal complex, and the process of depalatalisation assumed at this moment is the one affecting lexical preverbs located in the pretonic position of this morphological structure. In this sense, the Cambray Homily already has the form ma arfoimam (MS maar foim am) 'if we receive' (Thes. 2: 245.12) from ar.foim, with the lexical preverb ar- in pretonic position also found in later Old Irish texts. As stated in the previous section, the declarative form of the preverb ar- with third person singular masculine / neuter (i.e. are $/ a^{\mathrm{N} / \mathrm{L}}$ ) and the conjugated preposition aire 'for him, for it, therefore' are best explained from a previous form *ari-, whereas the conjunction air 'for' and the bare pretonic form of the lexical preverb (as ar- in the previous form of the Cambray Homily) could be derived from both ${ }^{\star}$ ari- and ${ }^{\star}$ are-. The expected palatalisation in the pretonic form of the lexical preverb in its declarative clause type form without infixed pronoun has suffered the process of depalatalisation of unstressed forms now under consideration.

14 To conclude the treatment of the so-called Early Old Irish attestation, the combination of the preposition ar- with the oblique relative conjunct particle $-(s) a^{\mathrm{N}}$ - in aire sechethar 'that he follow' (Thes. 2: 244.31) seems to maintain the palatal character of the pretonic sequence, but the same sequence shows no palatal character a couple of lines before in the same text: ara tinóla 'that he gather', are n-airema 'that he receive' (Thes. 2: 244.27-28), from do-inóla and ar.eim respectively. This conjunct particle, which is the outcome of a relatively recent process of internalisation of a previously autonomous sequence of preposition and demonstrative ${ }^{*} s a^{\mathrm{N}}$ (see the observations in García-Castillero 2018), may well have preserved some features of its previous situation. 
The important aspect for the question of the depalatalisation in preverb forms with Class A third person singular masculine / neuter infixed pronoun such as ( $\left.{ }^{\star} a \partial_{-} e[m]->\right){ }^{\star} a \partial^{j}{ }_{-}^{\mathrm{N} / \mathrm{L}_{-}}>$Old Irish ${ }^{\star} a d^{\mathrm{N} / \mathrm{L}_{-}}$and $\left({ }^{\star} e s s-e[m]->\right){ }^{\star} e s^{\mathrm{N} / \mathrm{L}}->$ Old Irish ${ }^{\star} a s^{\mathrm{N} / \mathrm{L}_{-}}$, as well as ${ }^{\star}$ foir ${ }^{\mathrm{N} / \mathrm{L}}->$ Old Irish ${ }^{\star}$ for $^{\mathrm{N} / \mathrm{L}_{-}}$is that its most adequate parallel is the form of the bare preverb ar- just considered, i.e. the form of the preverb used in the declarative clause type form without infixed pronoun, and this form already shows the depalatalised form in Early Old Irish, i.e. *ari/e- > ${ }^{\star} a r^{J}->a r$ - (in ar.foimam). The depalatalisation of unstressed elements can therefore be considered a relatively long process which takes place before and after the Early Old Irish period, but the crucial change assumed above in Table 6 for the lexical preverbs with the shape (-)VC- seems to have happened well before that time.

It is to be said that the homonymy between forms which can be included in the previous table is not always avoided. The two following cases can be mentioned. First, most lexical compounds with the deuterotonic shapes CV.VC(-) and $(-)$ VC.VC(-) make no systematic distinction between declarative and leniting relative clause type forms without infixed pronoun, so that e.g. do.adbat may be '(s) he shows' and 'who shows' or 'whom/which (s)he shows'; ad·aig, '(s)he drives' and 'who drives'. Second, verbs with the lexical preverb ar- have the same form for the relative clause type form and the declarative with third person singular masculine / neuter infixed pronoun (e.g. ara $^{\mathrm{L} / \mathrm{N}}$ gaib both 'who seizes' and '(s)he seizes it / him'). Note that the second case is the one which is being considered for the lexical preverbs taking Class B infixed pronouns.

In other cases, however, a more marked verbal complex is used to express the meaning of another form in which a phonological process has caused a certain disturbance in the distinction of the categories included in Tables 5 and 6 above. I refer to the case of the verb fo-fera 'produces, causes' included in Table 7 . In this verb, the regular form of the relative without pronominal infix is fo era, ${ }^{15}$ but this combination is also expressed by means of the relative form with pronominal infix: the form fodera must be interpreted simply as 'which causes' in $\mathrm{Wb} .3^{\mathrm{c}} 33$, Wb. $3^{\mathrm{c}} 34, \mathrm{~Wb} .5^{\mathrm{d}} 5$, Wb. $14^{\mathrm{c}} 42, \mathrm{Ml} .93^{\mathrm{a}} 13, \mathrm{Ml} .55^{\mathrm{d}} 11$, and as 'which causes it' in Wb. $33^{\mathrm{C}} 12, \mathrm{Ml} .32^{\mathrm{a}} 5$. The same use of the Class $\mathrm{C}$ infix deprived of any referentiality can be assumed for dodesta 'what is lacking', the relative form from the CV-VC(-) verb do.esta 'is lacking' which is used after the light heads $a^{\mathrm{N}}$ and aní 'that (what)'.

15 This form can be deduced from the past subjunctive fuerad 'that [Joshua] provided' (Wb. $\left.33^{\mathrm{b}} 13\right)$. The lack of $-f$ - in the leniting relative form fo era is the regular outcome of the lenition of $/ f /$. 
Table 7: $[ \pm 3$ rd person singular neuter pronominal infix] and the difference declarative vs. relative clause type in the lexical compound fo.fera 'causes'.

\begin{tabular}{lll}
\hline & Declarative clause type & Leniting relative clause type \\
\hline [- 3sg. neut. pronominal infix] & $\begin{array}{l}\text { fo fera } \\
\text { '(s)he causes' }\end{array}$ & $\begin{array}{l}\text { fo.era / fo-d.era } \\
\text { 'who causes' }\end{array}$ \\
\hline [+ 3sg. neut. pronominal infix] & $\begin{array}{ll}\text { fa.era } \\
\text { '(s)he causes it' }\end{array}$ & $\begin{array}{l}\text { fo-d.era } \uparrow \\
\text { 'who / that causes it' }\end{array}$ \\
\hline
\end{tabular}

Turning to the situation of homonymy resulting in Table 6 above, the remedy was to make use of the most marked form, i.e. the form originally used to express these infixed pronouns in a relative clause type verb, in order to express also the pronoun of the declarative clause type verb. This first step in the process leading to the creation of Class B infixed pronouns is illustrated in Table 8.

Table 8: $[ \pm$ 3rd person singular masculine / neuter pronominal infixes] and the difference declarative vs. relative clause type in a lexical compound with preverb (-)VC-.

\begin{tabular}{|c|c|c|}
\hline & Declarative clause type & Relative clause type \\
\hline [- 3sg. masc./neut. pronominal infixes] & $\begin{array}{l}\text { ad.cí } \\
\text { '(s)he sees' }\end{array}$ & $\begin{array}{l}a d \cdot{ }^{\mathrm{N} / \mathrm{L}} c i ́ \\
\text { 'who(m) / that ([s]he) sees' }\end{array}$ \\
\hline [+ 3sg. masc./neut. pronominal infixes] & $\begin{array}{l}{ }^{*}{ }^{N / 1} \in \dot{t} a t^{\mathrm{N} / \mathrm{L}} c i \leftarrow \\
\text { '(s)he sees him / it' }\end{array}$ & $\begin{array}{l}\left({ }^{*} a t^{\mathrm{N} / \mathrm{L}} \mathrm{c} \hat{I}\right) \\
\text { 'who / that sees him / it' }\end{array}$ \\
\hline
\end{tabular}

In spite of the different use of the relative form including the object pronominal reference, both processes assumed in Tables 7 and 8 share two remarkable features. First, in the initial situation, one of the expected forms turns out to be problematic, due either to its inherent structure (the hiatus resulting in the form fo.era), or to its lack of differentiation from another form $\left(a d^{\mathrm{N} / \mathrm{L}} \mathrm{ci}\right.$ as 'who[m] [(s)he] sees' and '(s)he sees him / it'). Second, the clearer (in the sense of formally more perceptible) form with infixed pronoun of Class $\mathrm{C}$ comes to the rescue in both cases: on the one hand, the relative form with neuter infixed pronoun (i.e. with Class C form) fo-d.era 'who causes it' lacks the phonotactically uncomfortable hiatus of the attested form foera and is used to express (also) the bare relative form 'who causes'; on the other, the assumed relative form with pronominal infix $a t^{\mathrm{N} / \mathrm{L}} \mathrm{ci}^{\prime}$ 'who sees him / it' has the advantage that it shows clearly the form of a pronominal infix and is used to express the declarative form with pronominal infix '(s)he sees him / it'. 
In both cases, of course, it is necessary to find a syntactic environment in which the use of the surrogate form can be justified.

\subsection{The bridging context}

In the previous section, the relative form with pronominal infix of both fo-fera and compounds with a lexical preverb ending in consonant such as ad·cí has been assumed to be the surrogate form for other forms which became problematic from the point of view of their morphological distinctiveness. The portmanteau morpheme which is the Class $C$ infixed pronoun, expressing both person/number and relative clause type character, is used to express only one of these two categories.

The specific syntactic environment and pronominal forms in which those two changes may have taken place constitute the 'bridging context' defined by Heine (2002: 86) as "a specific context giving rise to an inference in favor of a new meaning". ${ }^{16}$ As has been made clear in the previous section, the differences and similarities between the cases of the verb fo fera and of the verbs with a lexical preverb ending in a consonant must be clearly stated.

As for the use of fodera as the relative form of fo-fera, the most plausible scenario is provided by the cataphoric use of the third person singular neuter infix, a context in which the meaning of the pronominal marker can be lost. This cataphoric use of the Old Irish pronominal elements attached to the verbal complex has been studied by Lucht (1994) and, more recently, by Eska (2010). An example among many others is rafoiligestar (i.e. $r[o]-a^{(\mathrm{L})}$.foiligestar) in (8), in which the third person singular neuter infix $-a^{(\mathrm{L})}$ - cataphorically, i.e. proleptically (see GOI $\S 421$ ), refers to the object NP introduced by the light head $a^{\mathrm{N}}$ (anadfiadar is indsalm so) appearing later in the same sentence.

\begin{tabular}{|c|c|c|c|}
\hline rafoiligestar & nathan & duduid & \\
\hline AUG-3SG $\mathrm{NEUT}_{\mathrm{NET}} \cdot$ reveal $_{3 \mathrm{SG} . \mathrm{PRET}}$ & Nathan $_{\text {NOM }}$ & to= David $_{\text {DAT }}$ & \\
\hline anadfiadar & is & indsalm & so \\
\hline that ${ }^{\mathrm{NAS}} \mathrm{PV} \cdot \mathrm{relate}_{3 \mathrm{SG} . \mathrm{PRES} . \mathrm{REL} . \mathrm{PASS}}$ & in & the $_{\text {DAT.SG.MASC }}=$ psalm $\mathrm{DAT}_{\mathrm{DAT}}$ & PROX \\
\hline
\end{tabular}

16 The "bridging context", which Heine assumed to be a step in the process of grammaticalisation, should therefore also be considered in the process of paradigmatic split as the environment in which a functional change is possible. 
As for the use of a Class C pronominal infix, i.e. of an infix which is initially expected in a relative clause type form, to express the same pronominal reference in a situation in which a declarative clause type form could be expected, the most adequate bridging context is in the syntactic structures included above in Group II, since complement clauses and adverbial subordinates introduced by conjunctions such as amal 'as' or ( $h$ )óre 'because' show in the Old Irish glosses a certain degree of variation between declarative and relative clause type. The possibility of variation in those syntactic contexts basically involves the use of Class A instead of Class $\mathrm{C}$, and this would have been interpreted as a neutralisation of that difference.

An example of this situation is given in (9), where the third person plural infixed pronoun of Class A -s- observed in Table 2 above (i.e. a declarative clause type marker) is used in the verb after the subordinating conjunction hóre 'because', which is often accompanied by a nasalising relative verb. For this use, see Ó hUiginn (1986).

\section{(9) hóre nosmóidet iprecept

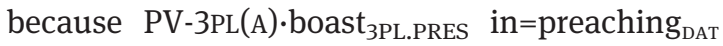 \\ 'because they boast in preaching, [. . .]' (Wb. 17 $\left.{ }^{\mathrm{C}} 5\right)$}

The form fritracatar quoted in (4b) above and repeated here in (10), from the verb fris.accai, is especially significant at this point. This example was adduced in section 3.4 as a case in which declarative morphology is used in a syntactic context in which relative morphology can also appear. In the light of the present diachronic hypothesis, the Class B third person singular neuter infixed pronoun in fritracatar may well be a case in which the original Class $\mathrm{C}$ form added to the original form of the preverb involved (i.e. ${ }^{\star} w r i \theta-+/-\partial^{\mathrm{L}}-/>/ \mathrm{frid}^{\mathrm{L}}-/$, spelt as frit-) was liable to an interpretation as a declarative clause type marker, i.e. in a place in which the declarative clause type Class A infix can also appear.

$$
\begin{aligned}
& \text { (10) [...]huare fritracatar som a deo } \\
& \text {... because PV-3SG } \mathrm{NEUT}_{\mathrm{N}}(\mathrm{B}) \cdot \mathrm{hope} \mathrm{AUG}_{\mathrm{APL} . \mathrm{PRET}}=3 \mathrm{SG}_{\mathrm{NEUT}} \text { from } \operatorname{God}_{\mathrm{ABL}} \\
& \text { '[. . .] because they have hoped for it a deo' (Ml. 131 } \left.{ }^{\mathrm{C}} 10\right)
\end{aligned}
$$

Most cases with first and second person infixed pronoun included in the column (II) of Table 3 perfectly represent the syntactic contexts in which this use of the third person singular masculine / neuter infixed pronouns of Class C 
would be reinterpreted as markers of declarative clause type due to their clearer form. In most cases of the column (III) of Table 3, the interpretation of the Class $\mathrm{B}$ infixed form as coming from a Class $\mathrm{C}$ form makes perfect sense: e.g. the form anatammresa 'when I will rise' included in Table 3, from the verb at.reig, appears in a structure in which relative morphology is otherwise compulsory, and this agrees with its diachronic interpretation as an originally Class $\mathrm{C}$ form.

Up to this point, the explanations for the relative form of fo-fera and for the rise of Class B infixed pronouns have run in quite a parallel fashion. They are different, however, in that in the first case, only one single pronominal element is involved, the third person singular neuter infixed pronoun, and one single lexical element. In the case of Class B of infixed pronouns, the whole pronominal paradigm comes into play and, in addition to that, there are quite a number of compound verbs involved, i.e. those which had a (-)VC- lexical preverb in the pretonic position.

\subsection{The mechanism of paradigmatic split}

It is time to delineate the morphological process by means of which two paradigms, i.e. Classes $\mathrm{B}$ and $\mathrm{C}$ of pronominal infixes, arise from a single one, i.e. Class C. For this purpose, the well-known case of paradigmatic split in which two Latin nouns, deus, deī 'god' and dīuus, dīuī 'deity, divine', have developed out of a single original paradigm, the one included in step (i) of Figure 1, may serve to illustrate the basic mechanism of this morphological change. The changes that occurred from step (i) to step (iib) of Figure 1 are of a phonological nature and trigger the later process of paradigmatic split. First, step (iia) shows the effect of the regular changes /-wo-/ > /-o-/ and /-ej-/ > /-e--/; forms with and without $/-w-/$ are thus created in the paradigm. In step (iib), the change from closed /- $\overline{\mathrm{e}}-/$ to $/-\overline{\mathrm{i}}-/$, which happens in forms such as the genitive and ablative singular but is prevented in other forms such as the nominative and accusative singular due to the shortening of that /-ē-/ in prevocalic position, causes a still clearer differentiation between those two groups of forms. Properly, the split is in step (iii), where each original group of forms analogically creates the missing parts of their paradigms.

The change from (iib) to (iii) in Figure 1 is graphically shown as the substitution of the horizontal by a vertical line, and this is an appropiate representation of the creation of two different paradigms from a situation in which two variants within one and the same paradigm were created.

I therefore assume two main steps for the process of paradigmatic split, first the introduction of some sort of variation within a given paradigm (ii) in 


\begin{tabular}{|c|c|c|c|c|c|c|c|c|}
\hline \multirow[b]{2}{*}{ nom.sg. } & (i) & \multirow[t]{2}{*}{$\rightarrow$} & (iia) & \multirow[t]{2}{*}{$\rightarrow$} & (iib) & \multirow[t]{2}{*}{$\rightarrow$} & \multicolumn{2}{|l|}{ (iii) } \\
\hline & *dejwos & & $>$ *dēos & & $>$ *deos & & $>$ deus & dīuus \\
\hline acc.sg. & *dejwom & & > *dēom & & $>{ }^{\star}$ deom & & $>$ deum $\downarrow$ & dīuum \\
\hline gen.sg. & *dejwī & & > *dēwī & & $>$ *dīwī & & deī & $>$ dīuī \\
\hline bl.sg. & *dejwōd & & $>$ *dēwōd & & $>{ }^{*} \operatorname{di} w \bar{o} d$ & & $d e \bar{o}$ & $>$ dīuō \\
\hline
\end{tabular}

Figure 1: The process of paradigmatic split leading to Latin deus, deī 'god' and dīuus, dīuĩ 'deity'.

Figure 1), and second the analogical creation of new forms corresponding to each of the original variants, thus giving rise to two different paradigms ((iii) in Figure 1), the existence of which must be justified on the basis of some functional or semantic difference, the basic requisite for any process of split in diachronic morphology (see García-Castillero 2013).

Accordingly, the paradigmatic split assumed for the creation of Class B as a distinct paradigm from the original Class $C$ is delineated in Figure 2, where the lexical preverbs aith- and uss- have been omitted. Note that the steps (ii) and (iii) include the forms in their usual Old Irish spelling.

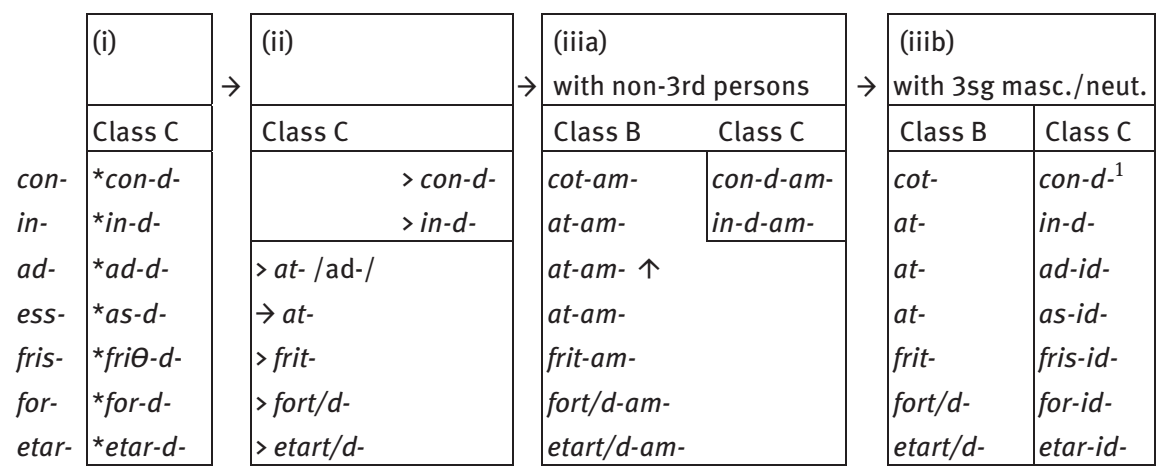

Figure 2: Paradigmatic split from original Class C to Old Irish Classes B and C.

${ }^{1}$ This lexical preverb con- combined in Old Irish with the Class $C 3^{\text {rd }}$ person singular masculine / neuter infix often appears as conid- ${ }^{\mathrm{N} / \mathrm{L}-}$ (e.g. Ml $106^{\mathrm{b}} 8$ lasse conidrerp 'when he has entrusted himself', from con-erbai). Though the consideration of this form conid- should also take into account the homonymous forms of the conjunct particle $c o^{\mathrm{N}}$ - 'so that' plus the same infix and of this conjunct particle combined with the copula, it seems that the analogical influence of the other forms with renewed Class C $3^{\text {rd }}$ person singular masculine / neuter form -id- (i.e. ad-idand so on) suffices to explain the form conid- in this combination of lexical preverb plus Class $C$ infix. I owe this observation to Elliott Lash (p.c.).

The forms given in step (i) of Figure 2 are those ones expected for Class C, which is characterised by the addition of the (already) relative marker ${ }^{*}-d V$ - to 
the bare form of the lexical preverb followed by the corresponding affixal pronoun. At this stage, there is no need to differentiate between non-third and third persons, and the regular developments assumed for each form arrived at the situation in step (ii) of Figure 2, with more or less transparent forms such as con- $d$-, in- $d$ - and for-t-, etar-t-, with other forms which are most easily explained as due to the fusion of the final dental with the initial dental of the infix (ad-, aith-, fris- in so far as this is from ${ }^{\star} f r i \theta$-), but also with forms in which the final consonant of the lexical preverb was apparently substituted by the form of the infixed pronoun beginning with - $t$ - /d/ (as in the case of ess-, oss- and - taken at its face value - fris-). The substitution of the final consonant which can be assumed for *ess- > as- $\rightarrow a(s)$-t- (and, mutatis mutandis, for oss- and friss-), would be of course a further case of replacive morphology, similar to that assumed in section 3.3 above for the third person singular masc./neut. forms of Class A with preverbs such as do-.

On the basis of that situation, step (iiia) of Figure 2 represents the first move towards the differentiation between Classes B and C for (-)VC- lexical preverbs, and corresponds to McCone's explanation below of the Class B forms cotand at-, from con- and in- respectively.

It has, of course, long been realised that con- $d(-)$ and in- $d(-)$, which actually do occur as class $\mathrm{C}$ forms in relative clauses, would be the regular outcome of the sequences * $k o m$ - $d e$ and ${ }^{*}$ in (de)-de- in main clauses too. The simple solution is to posit analogical creation of main-clause co-t(-) and $a-t(-)$ with loss of the preverb's final consonant as in most other cases such as $a-t(-)<{ }^{\star} a d-d e-$ or ${ }^{\star} e y-d e-<{ }^{\star} e y(z)$-de- in relation to ad- and $a s-\left(<{ }^{\star} e s s<\right.$ $\left.{ }^{\star} e \chi s\right)$ respectively or fri-t- $\left.<{ }^{\star} w r i d-d e-<{ }^{\star} w r i d(z)-d e-\right)$ in relation to fris $\left(<{ }^{\star}\right.$ writs $)$.

(McCone 2006: 229)

Apart from being a step in the development of a new distinction between Class B and Class C, the situation of step (iiia) in Figure 2, which includes the first person singular pronominal infix, reflects quite faithfully the description in section 4 for non-third person infixes of Class B, at least for most of the corresponding lexical preverbs. With respect to that situation, step (iiib) of Figure 2 represents the introduction of new forms for distinguishing Class $\mathrm{C}$ forms for the third persons, i.e. the creation of new relative clause type forms for the third person singular pronouns, in which the distinction between declarative and relative is in general more systematic.

The whole process of paradigmatic split may therefore be viewed in the change from step (ii) to step (iiib) in Figure 2: the horizontal line in step (ii) is partially put in the vertical position in step (iiia), as a consequence of the analogical creation of co-t(-) and $a-t(-)$, whereas the remaining horizontal part of that line ends up in the vertical position in step (iiib), as a consequence of the analogical creation of the forms for the third persons in the other lexical preverbs. 


\section{Conclusion}

The diachronic explanation for the Old Irish Class B of infixed pronouns argued for here is different to previous ones in some important respects. First, it pays special attention to the use of these forms in the contemporaneous Old Irish texts. Second, much in line with the basic tenets in García-Castillero (2015), it considers the interaction between phonological, morphophonological, morphological, and also syntactic aspects of the Old Irish verbal complex: in particular, it takes seriously the assumable phonotactic conditions of some grammatical distinctions such as clause type and pronominal references in lexical compounds with a (-)VC- lexical preverb, and how the morphologically undesirable consequences of some phonological changes can be avoided.

The starting point of the diachronic explanation put forward in this chapter is a situation in which there were only Classes A and C. The forms of the third person singular masculine / neuter infixed pronouns of Class $C$ were then used to express those persons when their Class A version had been obliterated by regular phonological changes with most lexical preverbs of the shape (-)VC-. The use of Class $\mathrm{C}$ instead of the vanished marking attributable to the original forms of Class A was facilitated in syntactic contexts in which both relative and declarative clause type morphology were possible, and the new 'declarative' forms were levelled through the whole paradigm, a process especially easy for the non-third persons, since the verbal complexes including those infixed pronouns seem to be less in need to distinguish between relative and declarative clause type forms, at least in view of the frequent use of Class A instead of expected Class C. This step in the development of Class B corresponds to the situation assumed for the non-third persons. In the next step, the third person infixes created a form different to the newly created Class B by adding the ending -id- to the bare form of the lexical preverb, thus renewing the form of Class $\mathrm{C}$ in those third persons.

This diachronic explanation does not need to go far back in the prehistory of the Irish language in order to explain the origin of Class B infixed pronouns and, in fact, it nicely fits in with the following descriptive issues observed in the language of the Old Irish glosses. First, it seems clear that the relevant factor for the use of Class B of infixed pronouns is the phonotactic structure of the involved lexical preverb in pretonic position, namely the structure (-)VC-. Second, this diachronic explanation also agrees with the default character of the infixes of Classes $\mathrm{A}$ and $\mathrm{C}$, which are used not only with (-)CVpreverbs, but also with the remaining conjunct particles. Third, other situations of homonymy which happen in the case of some specific verbs and under some specific circumstances (e.g. fo.fera 'causes') are sometimes 
corrected by using the more visible form. Fourth, the assumption that the third person singular masculine / neuter infixed pronouns constitute the locus of the whole change accords well with the fact that these forms are the most frequent infixes in the contemporaneous Old Irish texts, as clearly observable in Sommer's (1897) collection of forms. Fifth, it directly explains the remarkable asymmetric situation found in the language of the glosses in the use of the non-third persons of the Class B infixed pronouns, which turns out to be a specific step in the assumed process of paradigmatic split; this asymmetry agrees with general trends in the distribution of declarative and relative clause type marking in Old Irish.

As a general result of this study, the consideration of the process of paradigm split has also revealed the need of a 'bridging context' for this change, which is also essential in grammaticalisation processes. This is surely not a matter of chance. In fact, grammaticalisation is one of the possible sources of a new morpheme in a given paradigm, or of a new paradigm, and the consequence of the creation of these new morphological elements is that there is a morphological split so that the new morpheme or paradigm expresses a specific function or meaning, different to the meanings of the morphemes already existing in that paradigm or to the meanings of the already existing paradigm(s).

Acknowledgement: This is a revised version of a paper presented at the Teangeolaiocht na Gaeilge / The Linguistics of the Gaelic Languages XVII, held at the National University of Ireland Maynooth on 10-11 April 2015. I primarily have to express my gratitude to the editors for having accepted it in this volume. I am also indebted to the audience of the 2015 conference, in particular Jürgen Uhlich, for their comments. Elliott Lash, Fangzhe Qiu and an anonymous reviewer have also made important contributions to improve the quality of the paper. Remaining errors are my sole responsibility. Financial support has been received from the research group GIC 10/83, IT 486-10. 
